ARCFIVUM ANATOLICUM (ArAn)

\title{
HİTİTLERİN BATI KARADENİZ BÖLGESI'NDE YAŞAYAN KOMŞULARI HAKKINDA YENİ BULGULAR
}

\author{
F. Gülden $E K M E N^{*}$ \\ Hamza EKMEN** \\ Sezer SEÇER FIDAN $N^{* * *}$
}

\begin{abstract}
Makale Bilgisi
Article Info

Başvuru: 12 Ocak 2021 Received: January 12, 2021

Kabul: 17 Mart 2021

Accepted: March 17, 2021
\end{abstract}

\begin{abstract}
$\ddot{O} z$
Batı Karadeniz kiylsında bulunan İnönü Mağarası'nda yürütülen araştırmalarda, III. tabakaya ait ahşap tabanlar açı̆̆a çıkarılmışsır. Bu tabanlar üzerinde metalden yapılmış çok sayıda alet, süs eşyası ve silah ele geçmiştir. Yine aynı kontekste, iyi korunmuş bir adet tunç boğa heykelciği ve bir adet pişmiş toprak heykelcik bulunmuştur. Heykelcik başı, stil olarak Hitit tasvir sanatından taninan insan tasvirleri ile benzerlik göstermektedir. Buluntularin ele geçtiği ahşap tabanların her birinden alınan karbon örnekleri de Kal. M.Ö. 1431-1285 ile Kal. MÖ 1295-1123 aralı̆̆ını vermiștir. Bu
\end{abstract}

* Dr. Öğr. Üyesi, Zonguldak Bülent Ecevit Üniversitesi, Fen Edebiyat Fakültesi, Arkeoloji Bölümü, ekmengulden@gmail.com; ORCID: 0000-0002-6818-9431

** Dr. Öğr. Üyesi, Zonguldak Bülent Ecevit Üniversitesi, Fen Edebiyat Fakültesi, Arkeoloji Bölümü, ekmenhamza@gmail.com; ORCID: 0000-0002-3452-2494

*** Hititolog, sezersecer@hotmail.com; ORCID: 0000-0001-7959-8698 
bă̆lamda Batı Karadeniz Bölgesi'nde önceki yıllarda tesadüfen ele geçen Geç Tunç Çağı'na ait bazı tekil bulgulara ek olarak, ilk kez sistemli kazllarla, tanıml tabakalarda bulgular elde edilmiştir. Söz konusu bulguların Hitit kentlerinde ele geçen örnekler ile yakın benzerlik göstermesi, Batı Karadeniz Bölgesi'nin Hitit Ülkesi ile uzun yıllardır sorgulanan ilişkisi hakkında ipuçları sunmaktadır. Bu çalışmada söz konusu bulgular arkeolojik açıdan kapsamlı bir şekilde değerlendirilmiştir. Ayrıca, Hitit belgelerinde adından sıkça söz edilen ve bazı araştırmacılar tarafindan Batı Karadeniz Bölgesi ile ilişkilendirilen Kaşkalar ve Pala-Tum(m)ana eyaletlerinin bölgedeki olası lokalizasyonları tartışılmıştır.

Anahtar Kelimeler: İn̈̈ü Măgarası, Hititler, PalaTummana, Kaşka, Geç Tunç Çă̆l.

\section{New Findings about the Neighbors of the Hittites Living in the Western Black Sea Region}

\section{Abstract}

During the investigations conducted in İönü Cave, which is located on the Western Black Sea coast, wooden floors belonging to level III were unearthed. Numerous tools, ornaments, and weapons made of metal were found on these floors. A well-preserved bronze bull figurine and a terracotta figurine were also found in the same context. The head of the figurine is similar in style to the human depictions known from the Hittite art. The carbon samples taken from each of the wooden floors where the finds were found also indicated the periods between Ca. 1431-1285 BC and between Ca. 1295-1123 $B C$. In this context, in addition to some individual finds belonging to the Late Bronze Age that were accidentally uncovered in previous years in the Western Black Sea Region, the findings were obtained in the defined layers for the first time through systematic excavations. The fact that these findings are closely similar to the samples obtained in Hittite cities provides clues about the relationship of the Western Black Sea Region with the Hittite Country, which has been questioned for many years. In this study, these findings were evaluated comprehensively in archaeological terms. Furthermore, the possible localizations of the provinces of Kaskians and Pala-Tum(m)ana, which are frequently mentioned in the Hittite documents and associated with the Western Black Sea Region by some researchers, were discussed.

Keywords: İnönü Cave, Hittites, Pala-Tummana, Kaska, Late Bronze Age. 


\section{Giriş}

Batı Karadeniz Bölgesi sahip olduğu iklim ve coğrafi koşulları nedeniyle arkeolojik araştırmalar açısından oldukça zorlu bir coğrafyadır. Bu coğrafyada arkeolojik bulgu aramak adeta samanlıkta iğne aramaya benzer. Bu nedenle, 1950'li yıllardan itibaren bölgede yürütülen az sayıda yüzey araştırmasında bölgenin prehistorik kültürleri hakkında oldukça sınırlı veriler elde edilebilmiştir. İstisna olarak Yassıkaya Mevki kazılarında bölgenin Erken Tunç Çağı sonlarındaki durumunu yansıtan bulgular tabakaya bağlı elde edilebilmiştir. Batı Karadeniz'in bu zorlu coğrafi şekillerinin yanında Hitit çekirdek bölgesinin kuzeybatı sınırında yer alması ve bölgede Hititlerle bağlantılı yerleşimlerin bulunup bulunmayacağ öteden beri cevap bulunmayı bekleyen sorulardır. Diğer taraftan Hitit yazılı belgelerinde adından sıkça bahsedilen Kaşkaların, bu belgelerden hareketle Hitit ülkesinin kuzeyindeki dağlık coğrafyada yaşadığının anlaşılması, Kaşkaların Batı Karadeniz Bölgesi'ndeki varlığının sorgulanmasına sebep olmuştur. Yine Hitit metinlerinde adı geçen ve Hitit merkezi otoritesine bağlı olduğu anlaşılan Pala ve Tum(m)ana eyaletleri/ülkelerinin de Batı Karadeniz bölgesinde aranması gerektiği filologlar tarafindan önerilmektedir. Ancak, bugüne kadar bölgede yapılan araştırmalarda söz konusu halkların, şehirlerin ya da eyaletlerin varlığına dair neredeyse hiçbir arkeolojik ya da filolojik kanıt elde edilememiştir. Yanı sıra, bölgede Hitit sanatına uygun eşya, alet ve silahlar tesadüfen bulunmuş; bu eserler satın alma yoluyla müzelere kazandırılmıştır. Söz konusu eserlerin bulunduğu yerlerde yapılan araştırmalarda ise buluntuları, ilgili oldukları konteksleri ya da yapıları açıklayabilecek herhangi bir veri elde edilememiştir (Fig. 1). Esasında gerek Kaşka gerekse de PalaTum(m)na şehir veya topluluklarının yaşadıkları yerlerin nasıl bir yerleşim modelinde olduğu, çanak çömlek formlarının nasıl olduğu, küçük buluntularının nasıl bir karakter gösterdiği de tam olarak bilinememektedir. $\mathrm{Bu}$ nedenle araştırmaya nereden başlanacağı ve nasıl bir sonuçla karşılaşılacağı araştırmacıların en önemli sorunları arasındadır. Bu nedenle, elde edilemeyen verilere karşılık olarak araştırmacıların belki de haklı olarak verdikleri cevap bölgenin günümüzde olduğu gibi geçmişte de ahşap mimari karakterde olduğu ve çürümeye elverişli bu malzemenin günümüze kadar ulaşmadığ1 yönündendir. Ancak bölgenin sahip olduğu yer üstü ve yer altı zenginlikleri düşünüldüğünde ve Hitit çekirdek bölgesine yakınlığ 1 dikkate alındığında, her şeye rağmen bölgeyi Geç Tunç Çağı kültürleri açısından yoksun olarak tanımlayamayacağımız gerçeği ile karşı karşıyayız. Bu bağlamda Batı Karadeniz bölgesinde, Kdz. Ereğli kıyısından yaklaşık 30 km içeride bulunan İnönü Mağarası'nda bulunan Geç Tunç Çağı'na ait bulgular, bölge arkeolojisi ve Batı Karadeniz Bölgesi'nin Geç Tunç Çă̆ı'nda Hitit 
ülkesi ile olan ilişkilerini anlayabilmemiz açısından büyük öneme sahiptir. Bu çalışmada İnönü Mağarası, III. tabaka, Geç Tunç Çağı yerleşimi ve bu tabakada elde edilen Hitit kültürü ile bağlantılı buluntuların kapsamlı bir değerlendirilmesi yapılacaktır. Ayrıca bu çalışmada, söz konusu bulguların Hitit yazılı belgelerinde adlarından sıkça bahsedilen ve Batı Karadeniz bölgesi ile ilişkilendirilen Kaşkalar ve Pala, Tum(m)ana eyaletleri ile ilişkisi sorgulanacaktır.

\section{İnönü Mağarası}

Kızılırmak'ın doğusundan başlayarak, Sakarya Irmağı vadisine kadar uzanan engebeli ve gür ormanlarla kaplı Batı Karadeniz Bölgesi’nin zorlu coğrafyasında yer alan kıyı yerleşimleri, genellikle güney-kuzey istikametinde akarak Karadeniz'e ulaşan kısa mesafeli derelerin ağzında kurulmuşlardır. ${ }^{1} \mathrm{Bu}$ zor coğrafya, kuzey sınırını oluşturan Karadeniz ve hemen güneyinden başlayarak kıyıya paralel bir şekilde uzanan sıra dağlar tarafından adeta kuşatılmış gibidir. Bölgenin doğu-batı yönünde sıra dağlar şeklinde uzanan ve yükseklikleri yer yer 2000 m’ye ulaşan, geçit vermeyen dağlarını aşarak iç kesimlere ulaşmak bugün dahi oldukça zordur. $\mathrm{Bu}$ bakımdan günümüzde olduğu gibi geçmişte de Batı Karadeniz Bölgesi'nin iç kesimlerle güçlü kültürel bağlarının gelişmediği görülür. Bölgenin önemli akarsuları olan Filyos (Billaios) ve Bartın (Parthenios) çayları ve oluşturdukları vadiler bu sarp coğrafyada ulaşım açısından büyük öneme sahiptir. Ancak bu irmaklar da bölgenin doğusunda yer alan Kızılırmak (Halys) ve batı sınırını oluşturan Sakarya (Sangarios) gibi uzak mesafeleri birbirine bağlamamaktadır. Daha uzak mesafelere ulaşım ancak kısa mesafeli ırmak vadilerinin bittiği ve bir başka 1rmak vadisinin başladığı alanları takip ederek mümkün olmaktadır.

Batı Karadeniz'in dağlık coğrafyasında, kıyı ve iç kesimler arasındaki bağlantıyı ve ulaşımı sağlayan doğal güzergâhlardan biri de İnönü Mağarası'nın da içinde bulunduğu Gülüç Çayı (Lycus) vadisidir. Devrek yakınlarındaki yüksek dağlardan kaynağını alarak kuzeye doğru ilerleyen ve bünyesine kattığı c1lız derelerle debisini arttıran Gülüç Çayı yaklaşık 80 km mesafe kat ettikten sonra Karadeniz'e ulaşmaktadır. ${ }^{2}$ Gülüç Çayı vadisi aynı zamanda Batı Karadeniz kıyısında yer alan, klasik devirlerin büyük ve önemli kentlerinden biri olan Heracleia Pontika'nın periferisindeki önemli tarım alanlarını ve taşra yerleşimlerini bünyesinde barındırmaktaydı. Bununla

1 Ahmet Ünal, Eski Anadolu Siyasi Tarihi (Ankara: Bilgin Kültür Sanat Yayınları, 2018), 7879.

2 F. Gülden Ekmen, "İnönü Mağarası Kazıları Işı̆̆ında Kalkolitik Çağ’da Batı Karadeniz Bölgesi”, Tüba Ar 26 (2020): 47. 
birlikte, bu vadi Batı Karadeniz kıyılarını iç kesimlere bağlayan en kısa ve en kolay yol güzergâhını da oluşturmaktadır. Kdz. Ereğli'yi Devrek'e bağlayan Gülüç Çayı vadisi, İnönü Mağarası'nın bulunduğu alandan doğuya doğru takip edildiğinde Devrek'e ulaşılmaktadır. Buradan itibaren ikiye ayrılan yol, kuzeydoğu yönünde Devrek Çayı boyunca takip edildiğinde yaklaşık $15 \mathrm{~km}$ sonra bölgenin yerleşim açısından elverişli alanlarının bulunduğu Bakacakkadı, Çaycuma ve Filyos hattına ulaşılmaktadır. Söz konusu yol, vadi boyunca ilerlendiğinde Mengen, Gerede ve Bolu'ya dolayısıyla İç Anadolu'ya açılmaktadır. Bu önemli vadiye hâkim bir konumda bulunan İnönü Mağarası, $30 \mathrm{~km}$ kuzeyindeki Karadeniz kıyıları ile; güneye doğru ise iç bölgelerle kültürel ve ticari ilişkiler kurabilecek potansiyele sahiptir. 2017 y1lından itibaren mağarada yürütülen kapsamlı araştırmalar bu yönde önemli sonuçlar vermiştir. ${ }^{3}$

\section{Yerleşimin Yapısı ve Stratigrafi}

Birbirine bağlı A, B ve C adı verilen üç gözden oluşan İnönü Mağarası bir ana galeri (İnönü Mağaras1-1) ve kuzeybatısındaki dar bir geçitten geçilerek ulaşılan küçük bir kaya altı sığınăğ (İnönü Mağarası-2) olmak üzere iki kısımdan meydana gelmektedir. Ana galeri içinde gerçekleştirilen yoğun yüzey toplaması ve sonrasında yapılan kazılar, kültür dolgusunun B gözünün kuzey yarısına ve $C$ gözünün tamamına yayıldığını göstermiştir. A gözünde yapılan araştırmalarda yerleşim izlerini gösteren herhangi bir bulguya ulaşılmamıştır. Mağara zemini doğu-batı yönünde, yani dip kısmından ağız kısmına doğru belirgin bir şekilde eğimlidir. Ana galerinin batıya bakan geniş ve yüksek ağzı yaklaşık 10 m'yi bulan dik bir yamaç ile sonlanmaktadır.

Ana galerinin kuzeybatısında yer alan (yaklaşı 15 x 7,5 x 7 m) kaya altı sı̆̆ınağında (İnönü Mağarası-2) yapılan çalışmalarda herhangi bir bulguya rastlanmamıştır. Bu kısmın da ağız açıklığı dik bir yamaçla kesilmektedir. Mağaranın yapısal özellikleri dikkate alındığında, mağaraya girişin tıpkı günümüzde olduğu gibi geçmişte de güneybatıdaki dar kısımdan sağlanmış olduğu anlaşılmaktadır. Girişin batısındaki ve güneyindeki yamaçtan inilerek İnderesi'ne ve Gülüç Çayı'na kadar uzanan vadiye kolaylıkla ulaşılabilmektedir. Bu yamaçta görülen büyük andezit ve bazalt bloklarının mağaranın da içinde bulunduğu masif sırtın dik yamaçlarından koparak, bu kısma sürüklenmiş olduğu anlaşılmaktadır. ${ }^{4}$ Yerleşim izlerinin bulunmadığı

3 Hamza Ekmen, Ahmet Mercan, F. Gülden Ekmen, Ali Güney, "İnönü Mağarası 2018 Y1lı Kazı Çalışmaları" 41. Kazı Sonuçları Toplantısı, 2. Cilt (2020): 309 vd.

4 Hamza Ekmen, “İnönü Mağarası'nda Bulunan Erken Tunç Çağı'na Ait Sütten İkincil Ürün Üretiminde Kullanılan Bir Çömlek Üzerine Gözlemler”, H. G. Yalçın, O. Stegemeier (ed.), Metalurgica Anatolica, Festschrift für Ünsal Yalçın anlässlich seines 65. Geburtstags/Ünsal Yalçın 65. Yaşgünü Armağan Kitabı, (İstanbul: Ege Yayınları, 2020), 77 vd. 
A gözünde herhangi bir su kaynağ oluşturan $\mathrm{B}$ ve $\mathrm{C}$ gözlerinin doğusundaki duvar diplerinden kaynak suları sızmaktadır. Kültür dolgusunun bulunduğu bu kısımlar, su kaynakları nedeniyle yerleşim için tercih edilmiş olmalıdır. C gözünde, farklı alanlarda yürütülen kazılarda anakayaya kadar inilmiş ve yaklaşık 1,10-1,20 m kalınlığa ulaşan bir kültür dolgusunun var olduğu anlaşılmıştır. Bu dolgu içinde 5 kültür tabakası tespit edilmiştir. Mağaranın ilk sakinlerinin M.Ö. 5. Bin yılın son çeyreğinde (V. Tabaka), mağaraya yerleştiği anlaşılmaktadır. ${ }^{5}$ Bu tabakanın bir yangınla son bulmasının ardından, uzunca bir süre iskân edilmeyen mağaraya Erken Tunç Çağı'nda (IV. tabaka) tekrar yerleşildiği görülür. Bu tabakanın da şiddetli bir yangınla son bulmasının ardından Geç Tunç Çağı'nda (III. tabaka) mağaranın yeni yerleşimcileri tarafından kullanıldığı tespit edilmiştir.

\section{Tabaka: Geç Tunç Çağı}

Mimari Bulgular: Mağaranın $\mathrm{C}$ gözü sınırları içinde kalan İ/7, İ/8, İ/9, H/7 ve H/8 açmalarında III. tabakaya ait bulgular açığa çıkarılmıştır. Diğer tabakalara göre daha geniş alanlarda araştırılan III. tabakada, ahşaptan inşa edilmiş dört yapıya ait taban kalıntıları tespit edilmiştir (Fig. 2). Söz konusu kalıntılar A, B, C ve D yapıları olarak adlandırılmıştır (Fig 3). A yapısının kuzey kısmı Demir Çağı'na ait adak çukuru nedeniyle tahrip olmuştur. B yapısında ise, yakın zamana kadar mağarayı kullanan çobanların, mağara içinden sızan suları tahliye etmek için su arkları açmaları nedeniyle tahribat görülür. Birbirine bitişik konumda bulunan ve diğer iki yapıya göre daha büyük olan, A (yaklaşık 2, 35 × 3, 70 m) ve B (3,2 x 2 m) yapıları, kuzeydoğugüneybatı yönünde, daha küçük ölçülere sahip olan $C(1,7 \times 1,5 \mathrm{~m})$ ve $\mathrm{D}(1,6$ $\mathrm{x} 2,6 \mathrm{~m}$ ) yapıları ise güneydoğu-kuzeybatı yönünde uzanmaktadır. Söz konusu yapı tabanları, düzeltilmiş bir zemin üzerine tomrukların dört köşe oluşturacak şekilde bir kasnak gibi oturtulması ve ortadaki boşluğun işlenmemiş tomruklar döşenerek kapatılması şeklinde inşa edilmiştir. Dış hatlarda kullanılan kasnak tomruklarının köşeleri ise literatürde çantı tekniği olarak bilinen sistemde birbiri üzerine oturtulmuştur. Taban döşemesini oluşturan tomruklar, dış kasnakta kullanılanlardan daha incedir. Yapıların dışta bulunan ve iyi korunmuş durumda olan tomruklarının kalınlıklarının 12-15 cm'e kadar ulaşırken, içte bulunan ince tomrukların kalınlıkları ortalama 7-10 cm arasında değişmektedir. İçte ve dıştaki tek parça tomruklardan bazılarının uzunluğu 2,4 m'ye ulaşmaktadır. İnce tomruklar arasına yer yer küçük kazıklar çakılarak, hatılların kayması engellenmiş, yani sağlamlaştırılmıştır.

5 F. Gülden Ekmen, "İnönü Mağarası Kazıları Işı̆̆ında Kalkolitik Çağ’da Batı Karadeniz Bölgesi”, 50. 
Tabanların üzerinin ince kil bir sıva ile sıvandığı yapıların tabanları üzerinde yürütülen titiz çalışmalar sayesinde tespit edilebilmiştir. A ve B yapılarından alınan örnekler bu ağaçların Quercus L. cinsine ait olduğunu göstermiştir.

Çantı tekniği ile inşa edilen bu tabanların duvarlarına ilişkin ağaçlar ele geçmemiştir. 2020 yılı kazıları neticesinde ise, tabanların $C$ gözünün dipte kalan korunaklı kısmına doğru konumlandırıldığı belirlenmiştir. Buradan hareketle mağaranın en korunaklı kısmına inşa edilen ahşap yapılara duvar inşa etmeye ihtiyaç duyulmadığı düşünülebilir. Tabanlara ihtiyaç duyulmasının sebebi ise mağara içindeki yaşam koşullarını güçleştiren eğimdir. Geç Tunç Çağı sakinleri bu ahşap tabanlar sayesinde nemli ve eğimli olan mağara tabanı üzerinde, düz ve kuru bir yaşam alanı oluşturmuşlardır.

Küçük Buluntular: Yukarıda sözü edilen dört yapının tabanları üzerinde çanak çömlek parçaları ile pişmiş topraktan ve metalden yapılmış küçük buluntular ele geçmiştir. Oldukça özgün ve büyük ölçüde yerli karakter gösteren çanak çömlek parçaları, pişmiş topraktan yapılmış ağırşak ve tezgâh ağırlıklarının sayısı son sezonda yapılan kazılarla birlikte artmıştır. Çanak çömlek parçaları üzerinde yapılan ön incelemeye göre, ${ }^{6}$ III. tabakanın çanak çömlekleri, II. tabaka Erken Demir Çağı çanak çömlek geleneği ile büyük ölçüde uyumludur. II. tabakada bulunan el yapımı, kaba nitelikli, çoğu kabartma bant üzeri parmak baskı bezemeli çanak çömleklerin ${ }^{7}$ benzerleri III. tabaka ahşap tabanlarının üzerinde de ele geçmiştir. II. ve III. tabakadan elde edilen radyo karbon tarihleri ve kültür dolgusunun yapısal özelliklerine göre bu iki tabaka arasında bir boşluk olmadığı görülmektedir. Sadece mimari kalıntılarla birbirinden ayırt edilebilen bu tabakalar boyunca, seramik geleneğinin büyük ölçüde sürdürüldüğü anlaşılmaktadır.

III. tabaka tabanları üzerinde bulunan metalden yapılmış eşyaların sayısı ve çeşitliliği de dikkat çekmektedir. Aynı zamanda bu buluntular tarihleme ve yerleşimin karakterini anlama açısından büyük öneme sahiptir.

B yapısının tabanı üzerinde in situ pozisyonda bulunan kovanlı mızrak ucu tunçtan yapılmıştır ( $\mathrm{Cu} \%$ 86.5, Sn \%9.37, As \% 0.40) ve düşük omuzludur. Kovan kısmından bükülmüş bir biçimde ve uç kısmının bir kısmı kırık olarak ele geçmiştir. Kovan ile gövdenin birleştiği yerde, kazınarak yapılmış, birbirine paralel üç sıra çizgi, mızrak gövdesinin zıh kısmına doğru köşe yaparak birleşmektedir. Mızrak ucunun omuzları üzerinde metal bir

6 Söz konusu çanak çömlekler başka bir çalışmanın konusunu oluşturduğu için, konu ile ilgili detaylar burada sunulmamıştır.

7 Hamza Ekmen, F. Gülden Ekmen, Ali Güney, "İnönü Cave: New Results of the Early Iron Age Culture in the Western Black Sea Region”, OLBA XXVIII (2020): 40. 
halka da bulunmaktadır. Levhanın bükülmesi yöntemi ile yapılmıș olan bu halka mızrak ucunun sapa iyi tutunması amacı ile kullanılmıştır (Fig. 4).

A yapısının tabanı üzerinde ele geçen, üçgen gövdeli, tunçtan yapılmış $(\mathrm{Cu} \%$ 74.7, Sn \% 12.4) saplı hançerin gövdesi üzerinde MÖ. II. binyıl gözlü baltalarını anımsatacak bir biçimde iki adet göz bulunmaktadır. Sapın kabza ile birleştiği bölümde herhangi bir perçin kalıntısı bulunmamaktadır. Olasılıkla metal sap, ahşap kabzanın içine yerleştirilerek kullanılmıştır. Ahşap kabzanın kaymasını engellemek amacı ile sap kısmının kenarları dövülerek çıkıntı şeklinde yükseltilmiştir. Böylece sap kısmında çukur bir alan elde edilmiştir (Fig. 5).

H/8 açmasında, D yapısının tabanı üzerinde bulunan boğa heykelciği $(22,3724$ gr) tunçtan yapılmıştır $(\mathrm{Cu} \% 87.24 \mathrm{Sn}, \%$ 12.76) (Fig. 6). Dış yüzeyinde son halini vermek için yapılan çekiçleme izleri çıplak gözle görülmektedir. Enseden başlayıp, boynundan kuyruğuna kadar uzanan sırt hattı düz şekilde belirtilmiştir. Doğal anatomik yapısına göre kısa olan bacakları, sivri ucu kütleştirilmiş birer üçgen şeklindedir. Hilal biçimli boynuzları ve kuyruğu kare kesitlidir ve uçları sivriltilmiştir. Ağzı ise bir çizgi şeklinde belirtilmiştir (Fig. 7).

III. tabakanın küçük buluntuları içinde pişmiş topraktan yapılmış bir adet heykelcik başı da yer almaktadır. Boyun kısmından kırık olarak ele geçen baş, I/9 açmasının kuzey kesitine yakın bir yerde bulunmuştur. Olasılıkla C yapısına aittir. Kırmızımsı kahverengi (5 YR 5/3) hamuru taşçı, kum ve kireç katkılıdır. Yüzeyi hamur renginde bırakılmıştır. Başındaki sivri başlığın alın ile birleşen kısmında bir sarık mı yoksa tanrısallığ kabartısı mı olduğunu belirlemek oldukça zordur. Ablakça ifade edilmiş yüzünde, çıkıntı olarak belirtilmiş kemerli burnunun her iki yanında çubuk sokularak yapıldığı anlaşılan göz çukurları yer almaktadır. Sol gözünün üzerinde gösterilen kaşı çizilerek sola eğik olarak yapılmıştır. Kulakları ise verev bir çentik olarak gösterilmiştir. Burnun hemen altında bulunan ağzı ise daha kalın bir çubuk sokularak belirtilmiştir (Fig. 8).

\section{Değerlendirme}

\section{a) Arkeolojik Veriler}

Karadeniz bölgesinin gür ormanlarla kaplı, dağlık coğrafyasında yer alan dağınık yerleşimlerinde, geleneksel mimarinin temel inşa malzemesinin ahşap olduğu bilinmektedir. Bölgenin engebeli topografyası ve yoğun yağışlı iklim koşullarına dayanıklı olan ve aynı zamanda bol bulunan ahşabın zaman 
zaman kerpiç, taş ve tuğla ile birlikte kullanıldığı da görülür. ${ }^{8}$ Karadeniz bölgesinde yapıların inşasında ahşabın kullanıldığına ilişkin en eski verilere, Samsun-İkiztepe'de yapılan kazılarda ulaşılmıştır. Yerleşimin Geç Kalkolitik Çağ'a ait tabakalarında, temel kazılmadan çatılan dört köşe bir kasnağın üzerine işlenmemiş tomrukların köşelerden birbirine tutturularak yükseltilmesi ile oluşturulmuş yapıların bulunduğu tespit edilmiştir. $\mathrm{Bu}$ yapıların içten ve dıştan sıvandığı da belirtilmiştir. ${ }^{9}$ İnönü Mağarası, Geç Tunç Çağı ahşap tabanlarının inşa tekniği, İkiztepe'de tespit edilenler ile aynıdır. İkiztepe'de ahşap yapıların bazılarının tabanları sıkıştırılmış topraktan, bazılarının ise İnönü Mağarası'nda olduğu gibi ahşap tomruklardan yapılmıştır. İkiztepe'de Erken Tunç Çağı boyunca kullanımı devam eden çantı tekniğinin MÖ II. binyıl tabakalarında kullanılmadığ 1 dikkati çekmektedir. ${ }^{10}$ Araştırmacılar bu durumun, dönemin metal işçiliğindeki gelişmelerle ve alet çeşitliliğinin artmasıyla yakından alakalı olduğunu, inşa malzemesi olarak tomruğun yerini kerestenin almış olabileceğini belirtmektedir. ${ }^{11}$ İkiztepe dışında, bölgede Sinop-Kocagöz Höyük'te yapılan kazılarda tespit edilen yangın izlerinden yola çıkarak, yerleşimde inşa malzemesi olarak ahşabın yoğun olarak kullanıldığ 1 bildirilmiştir. ${ }^{12}$ Samsun-Dündartepe'de ise Kalkolitik Çağ'dan Hitit Çağı'na kadar olan tabakalarda temel taşına rastlanmaması ve ahşap duvar izlerini taşıyan kil parçalarının ele geçmesi nedeniyle mimaride ahşabın kullanılmış olduğu ifade edilmiştir. ${ }^{13}$ Fakat bu iki yerleşmedeki söz konusu ahşap yapıların hangi teknikte yapıldığına dair veriler tespit edilememiştir. Karadeniz Bölgesi dışında, Marmara Bölgesi'nde Bursa-Ilıpınar yerleşiminin Kalkolitik Çağ'a ait tabakalarında da ahşap mimarinin kullanıldığına ilişkin sonuçlara ulaşılmıştır. Ilıpınar ahşap yapılarının çantı tekniği ile değil, dikey olarak zemine çakılan ahşap direklerin aralarının dal ile örülerek, çit-örgü tekniği ile inşa edildiği belirtilmiştir. ${ }^{14}$ Çit

8 Celal Tuna, Orta Karadeniz Bölgesi Sahil Kesiminde Geleneksel Mimari. (İstanbul: Arkeoloji Sanat Yayınları, 2008), 43.

9 U. Bahadır Alkım, Handan Alkım, Önder Bilgi, İkiztepe II, Üçüncü, Dördüncü, Beşinci, Altıncı, Yedinci Dönem Kazıları 1976-1980, (Ankara: Türk Tarih Kurumu Yayınları, 2003), 38-42; Şevket Dönmez, Emine N. Dönmez, “Geç Kalkolitik Çağ’dan Günümüze Orta Karadeniz Bölgesi Kıyıları Kırsal Kesiminde Geleneksel Ahşap Mimari”, M. Alpaslan, Meltem Doğan-Alpaslan, Hasan Peker, (ed.) Vita, Belkus Dinçol ve Ali Dinçol’a Armağan, (İstanbul: Ege Yayınları, 2007), 219.

10 Alkım, Alkım, Bilgi, İkiztepe II, 38-42; Tuna, Orta Karadeniz Bölgesi, 51-55.

11 Tuna, Orta Karadeniz Bölgesi, 64.

12 Afif Erzen, "Sinop Kazıları 1953 Y1lı Çalışmaları”, Türk Arkeoloji Dergisi 6-1 (1956): 71.

13 İ. Kılıç Kökten, Tahsin Özgüç, Nimet Özgüç, "1940 ve 1941 Y1lında Türk Tarih Kurumu Adına Yapılan Samsun Bölgesi Kazıları Hakkında İlk Kısa Rapor”, Belleten IX/35 (1945): 368-370.

14 Jacob Roodenberg, "Stratigraphy and Architecture", J. Roodenberg (ed.), The Ilipinar Excavations I. Five Seasons of Fieldwork in NW Anatolia 1987-91, (İstanbul: Nederlands 
örgü tekniğinin kullanıldığı benzer uygulamalar Balkanlar'da Karanovo, Ezero gibi yerleşmelerde de tespit edilmiştir. ${ }^{15}$ Buradan hareketle, Karadeniz bölgesi dışında erken dönem yerleşimlerinde kullanılan ahşap yapıların inşa tekniğinin İnönü Mağarası örnekleri ile benzerlik göstermediği görülmektedir.

İnönü Mağarası ahşap yapıları, C gözünün dip kısımlarından sızan kaynak sularının kültür dolgusunu adeta bir balçığa çevirmesi ve dolayısıyla ahşapların oksijenle temasının kesilmesi nedeniyle oldukça iyi korunmuş durumdadır. Yapıların üzerinde ele geçen in situ buluntular aynı nedenle oldukça iyi korunmuştur. B yapısı üzerinde ele geçen ve bu çalışma kapsamında değerlendirilen kovanlı mızrak ucunun kullanımına dair en erken kanıt, Tepecik’te bulunan MÖ. 3. Binyıla tarihlenen taştan yapılmış kalıptır. ${ }^{16}$ $\mathrm{Bu}$ döneme ait metal örnekler henüz ele geçmemiştir. Bu tip mızrak uçları MÖ. II. Bin yılda yaygın kullanılmış, hatta Erken Demir Çağı başına kadar kullanımın sürdüğü bilinmektedir. Kaniş Karum'unun IV. ve III. tabakalarında, Asur Ticaret Kolonileri Dönemi'ne ait II ve Ib katlarında çok sayıda kovanlı mızrak ucu bulunmuştur. ${ }^{17}$ Hitit Çağı'na ait örnekler ise Alişar $^{18}$ ve Alaca Höyük'ten ${ }^{19}$ bilinmektedir. İnönü Mağarası örneğinde olduğu gibi, Alişar'da ele geçen mızrak ucunun da kovan kısmında metal halka bulunmaktadır. Anadolu dışında Balkanlar, Suriye, Mısır ve Levant'ta da bu tipte mızrak uçları yaygın kullanılmıştır. ${ }^{20}$

Ahşap yapılar üzerinde ele geçen bir diğer buluntu, A yapısı üzerinde in situ pozisyonda bulunan hançerdir. Anadolu'da bulunmuş en erken tarihli hançerler, MÖ. IV. binyılın sonuna tarihlenen Beycesultan ${ }^{21}$ ve Çamlıbel Tarlası $^{22}$ örnekleridir. MÖ. III. ve II. binyılda ise hançer kullanımı yaygınlaşırken,

Historisch-Archaeologisch Instituut te Istanbul, 1995), Fig. 10.

15 Dönmez, Dönmez, “Geç Kalkolitik Çağ'dan Günümüze Orta Karadeniz Bölgesi Kıyıları Kirsal Kesiminde Geleneksel Ahşap Mimari”, 220.

16 Ufuk Esin, “Tepecik Kazısı 1974”, Keban Projesi 1974-1975 Çalışmaları (Ankara: Orta Doğu Teknik Üniversitesi Keban Projesi Yayınları, 1982), 81.

17 Hayat Erkanal, "Die Äxte und Beile des 2. Jahrtausends in Zentralanatolien" Prähistorische Bronzefunde IX-8 (1977), 43, Lev. 15.

18 Hans Henning von der Osten, The Alişar Höyük Seasons of 1930-1982 Part II, (Chicago: The Universtiy of Chicago Press, 1937), Fig. 291/d2447.

19 Hamit Zübeyr Koşay, Mahmut Akok, Alaca Höyük Kazısı, (Ankara: Türk Tarih Kurumu Yayınlar1, 1966), 77, Lev. 47.

20 Graham Philip, Metal Weapons of the Early Bronze Ages in Syria-Palestine Part I-II, (Oxford: B.A.R., 1989), 366-368, Fig. 21-25.

21 Seton Lloyd, James Mellaart, Beycesultan Vol.I, (London: British Institute of Archaeology at Ankara, 1962), 282, Fig. F8-14.

22 Ulf Dietrich Schoop, "Çamlıbel Tarlası ve Kuzey-Orta Anadolu'da Geç Kalkolitik Dönem", İpek Önder (haz.) 1. Çorum Kazı ve Araştırmalar Sempozyumu (Çorum: Çorum Valiliği İ̀ Kültür ve Turizm Müdürlüğü, 2011): Resim 13. 
tiplerinin de çeşitlendiği dikkati çekmektedir. İnönü Mağarası hançeri, tipolojik açıdan MÖ. II. binyıl hançerleri ile uyum içerisindedir. Sap kısmındaki çıkıntısından yola çıkılırsa benzer tipte sapa sahip hançerler birkaç örnekle Alaca Höyük, ${ }^{23}$ Boğazköy $^{24}$ ve Alişar ${ }^{25}$ kazılarından bilinmektedir. Uluburun Gemisi'nde ele geçen benzer tipte kabzaya sahip bir hançerin, kabza kısmında ahşap kalıntılarının olması söz konusu çıkıntıların iç kısmına ahşap sapın nasıl yerleştirildiğini göstermesi bakımından önemlidir. ${ }^{26}$ Yukarıda sıralanan hançerler ile İnönü Mağarası hançerlerinin sadece kabza kısmı benzerlik göstermektedir fakat Ortaköy/Şapinuva' da M.Ö. 14. yüzyıla ait D binasında ele geçen iki hançer hem kabza hem de hançer yüzünde bulunan gözleri ile İnönü Mağarası örneğinin tam paralelleridir.

Ahşap tabanlar üzerinde ele geçen tunç eşyaların bir diğeri de boğa heykelciğidir. D yapısı tabanı üzerinde bulunan metal boğa heykelciği mağara içindeki bazı sembolik inançlar açısından ipuçları sunmaktadır. Anadolu ikonografisinde uzun bir süre boyunca sıklıkla görülen boğa tasviri, MÖ. III. Binyıla ait örnekleri ile Hatti ülkesinde sevilen bir unsur olduğunu göstermektedir. ${ }^{27}$ Asur Ticaret Kolonileri Dönemi tasvir sanatında da sıklıkla yer verilen boğanın, Eski Hitit Çağı'nda artık tanrısal bir sembole dönüştüğü görülür. Başta İnandıktepe ${ }^{28}$ ve Hüseyindede ${ }^{29}$ olmak üzere birçok yerleşimde ele geçen kabartmalı vazolar üzerinde boğanın çeşitli tasvirleri ile karşılaşılır. ${ }^{30}$ İnandıktepe ${ }^{31}$ Kuşaklı $^{32}$ ve Boğazköy' de ${ }^{33}$ bulunan boğa çiftleri, Hitit toplumunda boğanın kutsallığını gösteren en önemli buluntulardır. İnönü Mağarası'nda ele geçen tipte boğa heykelciklerinin pişmiş topraktan yapılmış,

23 Koşay, Akok Alaca Höyük Kazısı, Lev.133; Hayat Erkanal, "Die Äxte und Beile des 2. Jahrtausends in Zentralanatolien", Lev.13/30, 31, 34, 35, 36.

24 R. Michael Boehmer, Die Kleinfunde von Boğazköy (Berlin: Mann, 1972), Lev. IV/54.

25 von der Osten, The Alişar Höyük Seasons of 1930-1982 Part II, 253, Res. 287.

26 Ünsal Yalçın, Cemal Pulak, Rainer Slotta (ed.), Uluburun Gemisi 3000 Yll Önce Dünya Ticareti, (Bochum: Deutsches Bergbau-Museum, 2006), 623.

27 R. Oğuz Arık, Alacahöyük Hafriyatı 1935'deki Çalışmalara ve Keşiflere Ait ilk Rapor, (Ankara: Türk Tarih Kurumu Yayınları, 1937), Lev. CXCIX; Burhan Tezcan, "Yeni Horoztepe Buluntuları" Anadolu V (1961): Lev. XIX.

28 Tahsin Özgüç, İnandıktepe, Eski Hitit Çağı'nda Önemli Bir Kült Merkezi, (Ankara: Türk Tarih Kurumu Yayınları, 1988), 32, 52.

29 Tayfun Y1ldırım, "New scenes on the Second Relief Vase from Hüseyindede and Their Interpretation in the Light of the Hittite Representative Art" Studi Micenei ed Egeo-Anatolici Vol. L (2008): Fig. 2.

30 Özgüç, Inandıktepe, 32, 52.

31 Özgüç, Inandiktepe.

32 Andreas Müller-Karpe, Vuslat Müller-Karpe, "Kuşaklı-Šarišša” M. Doğan-Alpaslan, M. Alpaslan (ed.), Hititler, Bir Anadolu Imparatorluğu, (İstanbul: Yapı Kredi Yayınları, 2013), Fig. 5.

33 Peter Neve, "Die Grabungen aus Büyükkale" Mitteilungen der Deutschen Orientgesellschaft 95 (1965): 47-48. 
Eski Hitit Çağı'na ait örnekleri Alişar, ${ }^{34}$ Alaca Höyük ${ }^{35}$ ve Korucutepe'de ${ }^{36}$ bulunmuştur. Eski Hitit Çağı'na ait metalden yapılmış iki adet boğa heykelciği ise Sadberk Hanım Müzesi koleksiyonunda yer almaktadır. ${ }^{37}$ İmparatorluk Çağı'na ait iki adet boğa heykelciği Boğazköy'de bulunmuştur. Bunlardan birisi pandantif şeklindedir, ${ }^{38}$ Büyükkaya'da bulunan ikinci örnek ise tunçtan yapılmış olup, kalça kısmında bir delik ve bu deliğe geçirilmiş bir halka ile birlikte bulunmuştur. ${ }^{39}$ Büyükkaya'da bulunan bu boğa heykelciği, İnönü Mağarası'nda ele geçen boğaya oldukça benzemektedir. Yukarıya doğru yükselen boynuzları ve gövdenin üst kısmının düz bir hat şeklinde devam etmesi iki heykelciğin ortak özellikleridir.

III. tabakada bulunan bir diğer önemli buluntu, C yapısının kuzeybatısında bulunan kilden yapılmış ve baş kısmı korunmuş olan heykelciktir. Bu heykelcik, stilistik açıdan Hitit Çağı insan tasvirleri ile büyük bir benzerlik göstermektedir. Eski Hitit Çağı'na ait üç boyutlu insan tasvirlerinin sayısı oldukça azdır. ${ }^{40}$ Boğazköy'de ele geçen metalden yapılmış bir örnek ${ }^{41}$ ikonografik açıdan Sumer tasvir sanatını anımsatırken, Alaca Höyük'de ele geçen diğer örnek ${ }^{42}$ ise Mısır tasvir sanatının özelliklerini taşımaktadır. Bunlar dışında Eski Hitit Çağı'na ait insan tasvirlerine kabartmalı kaplar üzerinde rastlanmaktadır. Bu vazolar üzerindeki insan tasvirlerinde Hitit İmparatorluk çağı sanatından bildiğimiz sivri başlık pek görülmez. Ancak, Kaniş-Karumu Ib yapı katında bulunan altın bir folyo üzerindeki tanrı figürü Hitit tasvir sanatının bütün öğelerini taşımakta başında ise sivri başlık görülmektedir. ${ }^{43}$ Eski Hitit Çağı'na tarihlenen Dövlek heykelciği de sivri başlığı ve tanrısallığ 1 simgeleyen boynuzları ile betimlenmiştir. ${ }^{44}$ Hitit İmparatorluk Çağı'na ait üç boyutlu insan tasvirlerinin Eski Hitit Çağı'na oranla daha fazla

34 von der Osten, The Alişar Höyük Seasons of 1930-1982 Part II, Res. 237.

35 Koşay, Akok, Alaca Höyük Kazısı, 50, Lev. 29.

36 Hayri Ertem, Korucutepe I, 1973-1975 Kazı Yıllarında Ele Geçen Erken Hitit- Imparatorluk Çăgı Arası Buluntuları, (Ankara: Türk Tarih Kurumu Yayınları, 1988), 15.

37 Çetin Anlağan, Tanju Anlağan, Yeşim Günsenin, Hülya Yılmaz, Şebnem Akalın, Sadberk Hanım Müzesi, (İstanbul: Sadberk Hanım Müzesi, 1995), 23.

38 R. Michael Boehmer, Die Kleinfunde von Boğazköy, 168-169.

39 Jürgen Seeher, "Boğazköy-Hattuşa 1998 Yılı Çalışmaları", Koray Olşen, Fahriye Bayram, Adil Özme, Kemalettin Ataş, Haydar Dönmez, Ceyhan Süvari, (haz.) Kazı Sonuçları Toplantısı XX-I (Ankara: Kültür Bakanlığı Milli Kütüphane Basımevi, 2000): Res. 13.

40 A. Muhibbe Darga, Hitit Sanatı. (İstanbul: Akbank Kültür ve Sanat Kitapları, 1992), 34.

41 Kurt Bittel, Boğazköy I, Die Kleinfunde der Grabungen 1906-1912, (Leipzig: J. C. Hinrichs, 1937), Taf.1, 1a-b; Önder Bilgi, Anadolu'da Insan Görüntüleri, Klasik Çağ Öncesi, (İstanbul: Aygaz, 2012), 391.

42 Koşay, Akok, Alaca Höyük Kazısı, Lev. 31,14; Bilgi, Anadolu'da Inssan Görüntüleri, 390.

43 Fikri Kulakoğlu, "A Hittite God From Kültepe", Cécile Michel (ed.), Old Assyrian Studies in Memory of Paul Garelli, (Leiden: Nederlands Instituut Voor Het Nabije Ooste, 2008), 14, fig. 1.

44 A. Muhibbe Darga, Hitit Sanatı. 
olduğu görülmektedir. Tasvir edilen figürler ise çoğunlukla tanrılar, tanrıçalar, krallar, kraliçeler ve yöneticilerden oluşmaktadır. Bu genellemeye uymayan istisnai tasvirler az sayıdadır. İki boyutlu ve üç boyutlu olmak üzere, tasvir edilen figür kim olursa olsun belirli kalıplar şeklindedir. ${ }^{45}$ Bu kalıplar içinde en belirgin olarak göze çarpan unsurlardan birisi, külah şeklindeki sivri başlıktır. Bu başlık daha çok tanrı tasvirlerinde görülür, krallar ise genellikle takke biçimli başlıkla gösterilmektedir. ${ }^{46}$ Yüzdeki detaylara bakıldığında ise tüm tasvirlerde özellikle burun irice ve kemerli bir şekilde gösterilmiştir. Hitit İmparatorluk Çağı'na tarihlenen tanrı tasvirlerinin büyük bir çoğunluğu metalden yapılmıştır. Geri kalanları ise kil, fildişi ve kıymetli taşlardan üretilmişlerdir. Az sayıda ele geçen pişmiş toprak tanrı tasvirleri Boğazköy, Eskiyapar ve Alişar kazılarında bulunmuştur. Boğazköy'de ele geçen örneklerin birinde sivri bir başlık ile bir tanrı, ${ }^{47}$ diğerinde ise bir takkeyle kral ${ }^{48}$ tasvir edilmiştir. Tanrının sivri başlığı sarmal oluklar ile gösterilmiş, ablakça ifade edilmiş yüzünde iri gözleri ve iri burnu dikkat çekmektedir. Takkeli kral tasvirinde ise aynı karakteristik özellikler yanında, ağız kazınarak verilmiştir. Her ikisi de boyun kısmından kırıktır. Eskiyapar'da ele geçen bir örnekte ise sivri başlığı ile bir kral tasvir edilmiştir. ${ }^{49}$ Diğerlerinden farklı olarak kulakları deliktir. Alişar kazılarında bulunan üç örnekten ikisi tanrılara diğeri ise bir krala ait tasvirdir. ${ }^{50}$ Alişar'da ele geçen tanrı tasvirleri içinde bir örneğin baş kısmı, İnönü Mağarası'nda ele geçen heykelcik başı ile çok benzeşmektedir. Her iki örnekte de burun abartılı şekilde ifade edilmiş, ağızları ise birinde kazıma bir çizgi ile diğerinde ise bir çukurluk ile gösterilmiştir. Alişar örneğinde gözler ifade edilmemiş fakat İnönü Mağarası örneğinde gözler kazınarak verilmiştir. Bir tanrıyı temsil ettiği ifade edilen Alişar örneği ile büyük benzerlik taşıyan İnönü Mağarası heykelcik başının sivri başlığında yer alan ve alnı saran detayın boynuz olup olmadığ 1 konusunda kesin kanıya varmak güçtür. Ölçülerine bakıldığında İnönü Mağarası'nda bulunan heykelcik başının sadece baş kısmı $8.3 \mathrm{~cm}$ yüksekliğinde iken, Alişar'da ele geçen sağlam örnek, 5.5 cm'dir.

45 Bilgi, Anadolu'da İnsan Görüntüleri, 409.

46 Bilgi, Anadolu'da İnsan Görüntüleri, 424.

47 Kurt Bittel, Thomas Beran, E. Maria Bossert, Franz Fischer, Heinrich Otten "Vorläufiger Bericht über die Ausgrabungen in Boğazköy im Jahre 1956", Mitteilungen der Deutschen Orient-gesellschaft 89 (1957): Abb. 4a-c; Bilgi, Anadolu'da İnsan Görüntüleri, 424.

48 Anreas Schachner, "Die Ausgrabungen in Boğazköy-Hattuscha 2006" Archäologische Anzeiger 2007/1: 5a-b; Bilgi, Anadolu'da İnsan Görüntüleri, 424.

49 H. Hamdi Ekiz, “Çorum Müzesi'nde Bulunan Bir Hitit Tanrı Heykelciği Başı”, Kubaba: Arkeoloji-Sanat Tarihi-Tarih Dergisi 7 (2006), Res. 1-4; Bilgi, Anadolu'da Insan Görüntüleri, 424.

50 von der Osten, The Alişar Höyük Seasons of 1930-1982 Part II, Fig. 231, 234; Bilgi, Anadolu'da Insan Görüntüleri, 414, 424. 


\section{b) Batı Karadeniz Bölgesi ile ilgili Filolojik Veriler}

MÖ. 2. binyıl Anadolu coğrafyasına bakıldığında Hatti Ülkesi dışında pek çok ülkenin varlığı bilinmektedir. Ancak bu ülkelerin sadece bir kısmının lokalizasyonları ve hinterlantları saptanabilmiştir. Hatti Ülkesi ile temas halinde olan ve haklarında çok sayıda yazılı belge olmasına karşın halen lokalizasyonları tartışmalı olan birçok ülke mevcuttur. Karadeniz ve çevresi, bu tartışmalara en çok sahne olan bölgelerden birisidir. Kaška Ülkesi, Pala ve Tum(m)ana Ülkesi gibi ülkelerin bu bölgede yer aldığ 1 düşünülmektedir. Ancak bu ülkelerin dönem dönem Hatti Ülkesi ile farklılaşan ilişkileri ve buna bağlı olarak da değişen sınırları sebebiyle lokalizasyonlarını tam olarak yapmak güçtür.

Kaška Ülkesi: Kaškalar hakkındaki bilgiler, ağırlıklı olarak Hitit (Boğazköy, Ortaköy ve Maşathöyük) ve Mısır kaynaklarından elde edilmektedir. $\mathrm{Bu}$ belgelerden edinilen genel kanı ise Kaškaların Hititler ile hiç de dostane bir ilişki kurmamış olduklarıdır. Öyle ki, Hititler Kaškaları; dampupi- "vahşi, barbar" şeklinde tanımlamaktadırlar. $\mathrm{Bu}$ tanım olasılıkla Kaškaların dağlık alanda yaşamaları ve saldırgan yapıları nedeniyle kullanılmış olmalıdır.

Hitit metinlerinde Kaškalar; Kaška, Gašga ve Kašga yazım şekilleri ile karşımıza çıkmaktadır. Bu isim kendisinden önce, URU, KUR ${ }^{\mathrm{URU}}$, KUR.KUR, KUR.KUR.MEŠS ${ }^{\text {URU }}$ gibi determinatifler almaktadır. ${ }^{51}$ Kaška adı Hitit arşivleri dışında, az sayıda da olsa başka kaynaklardan da bilinmektedir. ${ }^{52}$

Forrer Kaška Ülkesi'ni Yeşilırmak ve Çekerek Nehirleri arasına yerleştirmekteyken, ${ }^{53}$ söz konusu halkın Kızılırmak'ın yukarı kısmıyla Yukarı Fırat arasında yaşadıklarını savunanlar da mevcuttur. ${ }^{54}$ Cavaignac, Kaškalar için çizdiği bölgeyi oldukça geniş tutarak Kızılırmak'ın alt bölümünden yaklaşı olarak Ege Denizi'ne dek uzatmaktadır. ${ }^{55}$ Goetze ise önceleri Hatti ve Arzawa arasındaki bölgede bulunduklarını düşünürken ${ }^{56}$ daha sonraları

51 Guiseppe F. del Monte, Johann Tischler, Die Orts-und Gewässernamen der hethitische Texte, (Wiesbaden: Dr. Ludwig Reichert Verlag, 1978), 190-191.

52 Ahmet Ünal, Hititler Devrinde Anadolu II, (İstanbul: Arkeoloji ve Sanat Yayınları, 2003), 48.

53 Emil Forrer, “Ausbeute aus den Boğazköi-Inschiften”, Mitteilungen der Deutschen Orientgesellschaft 61, (1921): 21.

54 L Ary Mayer, John Garstang, Index of Hittite Names, (London: Council, 1923), 14, 55; Bedrich Hrozny, Die älteste Geschichte Vorderasiens und Indiens. 2. Auflage, (Prag: Melantrich, 1943), $52 \mathrm{vd}$.

55 Eugène Cavaignac, "L'extension de la zone Gasgas a I Quest", Revue Hittite et Asianique 4, (1931): $101 \mathrm{vd}$.

56 Albrecht Goetze, "Kleinnasien zur Hethiterzeit, Eine geographische Untersuchung”, H. Bergstaesser, F. Boll (ed.), Orient und Antike, (Heidelberg: 1924), 28 vd. 
Sinop-Ordu arasında kalan bölgeye yoğunlaşmıştır. ${ }^{57} \mathrm{Bu}$ görüş, GarstangGurney ve Forlanini tarafindan da desteklenmiştir. ${ }^{58}$ Ayrıca birçok bilim insanı Kaška Ülkesi'nin doğuda Azzi-Hayaša, güneyde Yukarı Ülke (KUR ${ }^{\text {URU }}$ $\left.\mathrm{UGU}^{\mathrm{TI}}\right)$, batı da ise Pala-Tum(m)ana ile sinırlandığını iddia etmektedir. ${ }^{59}$ Görülebileceği gibi, Kaška Ülkesi'nin lokalizasyon çalışmalarına bakıldığında asıl problem ülkenin yayılım alanının belirlenmesidir. ${ }^{60}$ Yazılı belgelere bakıldığında, Eski Hitit Dönemi'nde Kaška adının yer almadığ 1 görülür. Ancak bu döneme atıflarda bulunan ve İmparatorluk Dönemi'ne tarihlenen metinler mevcuttur. ${ }^{61}$ Orta Hitit Dönemi'ne tarihlenen yazıll kaynaklara bakıldığında, ilk kez I. Arnuwanda ve eşi Ašmunikal'in dua metninde, ${ }^{62}$ Kaška adının yer aldığı görülür. ${ }^{63}$ Metninde, Kaškaların yapmış oldukları yağma ve yıkımlardan detaylıca bahsedilmektedir. Söz konusu metinde Kaškaların ele geçirdikleri Hitit toprakları da sıralanmaktadır. ${ }^{64}$ III.

57 Albrecht Goetze, "Bemerkungen zu dem hethitschen Text AO 9608", Revue Hittite et Asianique 1 (1930): $24 \mathrm{vd}$.

58 John Garstang, O. Robert Gurney, The Geography of the Hittite Empire, (London: British Institute of Archaeology at Ankara, 1959), Harita 1; Massimo Forlanini, Massimiliano Marazzi, Atlante Storico del Vicino Oriente Antico 4. 3 Anatolia, (Roma: L'impero Hittita, 1986), Çiz. 16-20.

59 Einar von Schuler, Die Kaskäer, (Berlin: De Gruyter, 1965), 13; Hayri Ertem, Hitit Devletinin İki Eyaleti: Pala Tum(m)ana ile yakın çevrelerindeki Yerlerin Lokalizasyonu Üzerine Yeni Denemeler, (Ankara: Ankara Üniversitesi Dil ve Tarih-Coğrafya Fakültesi Yayınları, 1980), 13, 18, 19; Leyla Murat, "Hitit Dünyasında Gaşgaların Yeri”, Sedat Alp, Aygül Süel (haz.) III. Uluslararası Hititoloji Kongresi Bildirileri 16-22 Eylül 1996, (Ankara: Uyum Ajans, 1998): 436; Leyla Murat, "Hitit Coğrafyasında Yukarı Ülke ve Tarihi Önemi”, Sekine Karakaş (haz.) Türkiye'de Sosyal Bilimlerin Gelişmesi ve Dil ve TarihCoğrafya Fakültesi Sempozyumu Bildiriler (Ankara: Ankara Üniversitesi Dil ve TarihCoğrafya Fakültesi Yayınları, 1998); Ünal, Hititler Devrinde Anadolu II, Harita 1; Jak Yakar, Ali Dinçol, "The Archaeology of the Kaška", IV Congresso Internazionale di Hitologia, Roma, 5-9 Settembre 2005, SMEA Vol.L-II (2008): 821.

60 Zira kuzeyinde Karadeniz'in doğal bir sınır teşkil ettiği düşünüldüğünde güney sınırını Hitit çekirdek bölgesi ve doğu sınırını ise Azzi-Hayaşa Ülkesi oluşturmaktadır. Bu durumda asıl tartışmalı olan nokta batı yayılım alanıdır. Ünal Kaškaların, Kastamonu'dan Sinop'a ve oradan da batıya doğru uzanarak Bolu'ya dek olan alanda farklı topluluklarla birlikte yaşamış olabileceğini ile sürmektedir (Ünal, Hititler Devrinde Anadolu II, 54). Ayrıca Ünal, Kaškaları konu alan metinlerde Kaškalar ile deniz ilişkisine dair bir verinin olmayışına dikkat çekmekte ve Kaška topluluklarının Karadeniz kıyılarına yakın alanlarda yerleşmemiş olabileceklerini ifade etmektedir (Ünal, Hititler Devrinde Anadolu II, 55).

61 II. Hattušili Dönemi'ne ait bir metinde KUB 21.29 Vs. II 1-5. CTH 89. Ayrıca, II. Hattušili ve IV. Tuthaliya'ya ait metinlerde; II. Hattušili'nin Otobiyografisi, Rs. II 46 vd.-CTH 81; KUB XXI 29 Vs. I 11 vd.-CTH 89 ve II. Muršili'nin Annallerinde; KUB 19.39 Vs. II 1-14. CTH 61. Ertem, Hitit Devletinin İki Eyaleti, $87 \mathrm{vd.}$

62 KBo 51.16-CTH 375.

63 von Schuler, Die Kaskäer, 29 vd; Ünal, Hititler Devrinde Anadolu II, 51.

64 Nerik, Huršama, Kaštama, Šerisa, Himmuwa, Taggašta, Kammama, Zalpuwa, Kapiruha, Hurna, Dankušna, Tapašawa, Kazzapa, Tarukka, İlaluha, Zihhana, Sipidduwa, Uašhaia ve 
Tuthaliya Dönemi'ne gelindiğinde; Kaškaların Hattuşa'yı dahi yağmalayarak, kraliyet ailesinin geçici bir süre Šamuha'ya (Kayalıpınar?) yerleşmesine sebep oldukları görülmektedir. ${ }^{65}$ Böylelikle Kaškaların bu süreçte Nevşehir Nenezi olduğu düşünülen Nennašša'ya dek indikleri anlaşılır. ${ }^{66}$

Hitit İmparatorluk Dönemi'ne gelindiğinde I. Šuppiluliuma'nın, ${ }^{67}$ Kaška saldırılarına hızla müdahale edebilmek amaciyla Tum(m)ana ve İštahara'da garnizonlar kurdurduğu görülür. ${ }^{68}$ Ancak bu önlemlerin yetmediği II. Muršili'nin Kaška şehirleri69 ile mücadelesinin devam etmesinden anlaşılmaktadır. Kaška Ülkesi'nin, Hatti için tekrar asker vermesini sağlamış olduğundan bahsedilse de bir dua metninde de ${ }^{70}$ Kaška Ülkesi'nin vergi ödemeyi bırakarak Hatti Ülkesi'ne tekrar saldırdıkları ifade edilmektedir. II. Muršili'nin y1llıklarında ise, Pihhuniya adlı Kaškalı bir liderin, Kaška'da yer alan birçok kabile reisinin üzerinde bir kral olarak hüküm sürmeye başlamasından bahsedilmektedir. II. Muršili Kaška Ülkesi içinde artık kendisine bir muhatap bulabilmesi nedeniyle, Kaška Ülkesi’ne götürülmüş olan tebaasını Pihhuniya'dan geri istemiştir. Olumlu bir yanıt alamayınca ise bir sefer düzenleyerek Pihhuniya'yı yenmiştir. ${ }^{71}$

Patalliia (Garstang, Gurney, The Geography of the Hitite Empire, 6 vd; Murat, "Hitit Dünyasında Gaşgaların Yeri”, 437.)

${ }^{65}$ KBo 6.28 Vs. I 6-8-CTH 88; Murat, "Hitit Dünyasında Gaşgaların Yeri”, 441; Theo van den Hout, "Hitit Krallığı ve İmparatorluğu'nun Kısa Tarihi”, Meltem Doğan-Alpaslan, Metin Alpaslan (ed), Hititler, Bir Anadolu İmparatorluğu, (İstanbul: Yapı Kredi Yayınları, 2013), 30.

66 Murat, "Hitit Dünyasında Gaşgaların Yeri", 441; Murat, Anadolu'da Kaškalar, 58.

67 I. Šuppiluliuma'nın Kaškaların kabilelerden oluştuklarını ifade ediyor oluşu, onların yönetimleri hakkında bilgi sunmaktadır (KUB 19.11 Rs. IV 1 vd.-CTH 40; KUB 14.3 Rs. III 2-27-CTH 181) Kaškaların bir türlü kontrol altına alınamayışının ardında, yönetimlerindeki bu çok başl1lık yatıyor olabilir (von Schuler, Die Kaskäer, 134 vd.).

68 KBo 2.5 Rs. IV 18 vd.- CTH 61. T. Robert Bryce, "The Boundaries of Hatti and Hitite Border Policy”, Tel-Aviv, Vol 13-14 (1986-1987): 65 vd.

69 İšhupita, Durmitta, Piggainariešša, Iahriešša, Timmuhala ve Tipiia.

70 KUB 24.3 Vs. II 45-50-CTH 376. Ayrıca bu metinde Kaškalar için "domuz çobanı ve dokumacı" ifadelerinin kullanılmış olması dikkat çekmektedir (Ahmet Ünal, "Hethitische Hymnen und Gebete", Otto Kaiser (ed.) Orakel, Rituale Bau- und Votivinschriften Lieder und Gebete (TUAT II/6) (Gütersloh: Gütersloher Verlagshaus Gerd Mohn, 1991): 803-808, Itamar Singer, Harry Hoffner, Hittite Prayers, (Atlanta: Society of Biblical Literature, 2002), 49-54.) Oysaki Kaškaların sadece hayvancılıkla uğraşmadıkları tarımla da ilgilendikleri bilinmektedir (Einar von Schuler, "Kaskäer", Reallexikon der Assyriologie 5 (1976-80): $460 \mathrm{vd}$.

71 KBo 3.4 III 67-93; KUB 14.17 II 30-39; KUB 19.30 I 8-20-CTH 61; Marie-Claude Trémouille, ${ }^{d}$ Hebat, Une Divinité Syro-Anatolienne, Eothen 7, (Firenze: Logisma, 1997), 29; Harry A. Hoffner, "Asyndeton in Hittite", Detlev Groddek, Marina Zorman (ed), Tabularia Hethaeorum-Hethitologische Beiträge Silvin Košak zum 65. Geburtstag, (Wiesbaden: Harrassowitz Verlag, 2007), 393. 
II. Muwatalli Dönemi'nde Hitit ile Mısır arasında baş gösteren sorunların daha hızlı bir şekilde kontrol altına alınabilmesi ve belki de mevcut Kaška saldırılarının uzağında kalabilmek amacı ile başkent Tarhuntašša'ya taşınmış ve Yukarı Ülke ile kuzey bölgelerinin hâkimiyeti II. Hattušili’ye ${ }^{72}$ bırakılmıştır. ${ }^{73}$ Hitit tarihinde belki de en dikkat çeken durum, II. Muwatalli döneminde Kadeš Savaşı'na (MÖ. 1274) Kaškaların II. Hattušili'nin komutasında ve Hititlerin yanında ${ }^{74}$ katılmış olmalarıdır. ${ }^{75}$ Savaşı konu alan Mısır yazıtlarında Kaška adı (Kškš) şeklinde yer almaktadır. ${ }^{76}$ II. Hattušili daha sonra, Hantili'den bu yana Kaška topraklarına dahil edilmiş olan ve Samsun Vezirköprü yakınlarındaki Oymaağaç olarak lokalize edilen Nerik'i de geri alarak Nerik Kültü'nü de tekrar buraya taşımış ve kenti yeniden inşa ettirmiştir. ${ }^{77}$

Pala ve Tum(m)ana Ülkeleri : Pala yer adı, yazılı belgelerde ilk defa MÖ. 2. binin ilk çeyreğine ait Eski Asurca metinlerde yer almaktadır. ${ }^{78}$ Hitit arşivlerinde ele geçen belgelere bakıldığında, bu ismin önüne KUR URU, KUR ya da URU determinatiflerinin geldiği görülür. ${ }^{79}$ Metinlerde Pala Ülkesi'nin, Tum(m)ana ve Kaška ile birlikte anılması yakın konumlarına işaret ediyor olmalıdır. II. Hattušili'nin kuzey bölgesinin kontrolünü sağlaması amaciyla kendisine verilmiş yerler arasında Pala Ülkesi'nin de adının geçmesi bu varsayımı desteklemektedir. Bu sebeple Pala ve Tum(m)ana Ülkelerinin lokalizasyonları da İnönü Mağarası'nın MÖ. 2. binyıldaki yerini ve önemini anlamada önem arz etmektedir.

72 I. Hattušili ile III. Hattušili arasında ikinci bir Hattušili’nin varlığının muallak olmasından dolayı III. Hattušili yerine yayınımızda II. Hattušili ifadesi kullanılmıştır. Bkz. Stefano De Martino, Du Kussara a Karkemish Storia del Regno Iftira. (Firenze: Logismo Editöre, 2016), 116

73 II. Hattušili'nin Otobiyografisi, Vs. I 22-27- CTH 81; Heinrich Otten, Die Apologie Hattusilis III: das Bild der Überlieferung (Wiesbaden: Otto Harrassowitz, 1981): 6 vd. ; van den Hout, "Hitit Krallığı ve İmparatorluğu'nun Kısa Tarihi”, 36.

74 Kaškaların da Hatti ordusuna açıkça düşmanlıklar gösteren Lukka halklarında olduğu gibi, çıkarlarını koruma amacıyla savaşa katıldıkları düşünülmektedir (Sezer Seçer, Yazılı Belgeler Işığında Lukka, Pedašša ve Walma Ülkeleri'nin Tarihi ve Tarihi Coğrafyası. İstanbul Üniversitesi, Hititoloji Bilim Dalı, Yayınlanmamış Yüksek Lisans Tezi, (İstanbul: 2012), 141

75 van den Hout, "Hitit Krallığ1 ve İmparatorluğu'nun Kısa Tarihi”, 36.

76 Alan Gardiner, Geschichte des Alten Aegypten, (Stuttgart: Alfred Kröner Verlag, 1965), 4053.

77 II. Hattušili'nin Otobiyografisi, Rs. III 45-54- CTH 81. Otten, "Die Apologie Hattusilis III", $20 \mathrm{vd}$.

78 Sedat Alp, Hitit Çağında Anadolu Çivi Yazılı ve Hiyeroglif Yazılı Kaynaklar, (Ankara: Tübitak Yayınları, 2000), 17.

79 Del Monte, Tischler, Die Orts-und Gewässernamender hethitische Texte, 297. 
Forrer Pala Ülkesi için, Blaene kentine (Çorum-Karg1), ${ }^{80}$ Schuler ve Kammenbuher'in görüşleri önderliğinde ise Ertem, Çaldağ1-Tavşandağ1 ve İnegöl Dağı arasındaki bölgeye işaret etmektedir. ${ }^{81}$ Ünal, Osmancık ve Vezirköprü civarına, ${ }^{82}$ Yakar ve Dinçol ise Antik Paflagonya bölgesine identifiye etmektedir. ${ }^{83}$ Pala Ülkesi'ni Tum(m)ana'nın batısında ya da güneybatısında, günümüzdeki Tosya'da $\operatorname{arayanlar}^{84}$ ve Ankara'nın biraz kuzeyinde Terme ile Çubuk Çaylarının verimli ovalarında aranmasını öngörenler ${ }^{85}$ de mevcuttur. Son lokalizasyon denemelerine bakıldığında; Forlanini'nin Köroğlu Dağları'nın kuzeyinde, Bolu ile Devrez Çayı arasına odaklandığ1 görülür. Ancak bu konumu, Billaias havzasının kuzeyine; yani Yenice Irmağ 1 , Filyos ve Bolu çaylarının (Devrek) kesiştikleri yer olan Gökçebey ilçesinin kuzeyine dek taşıma eğiliminde olduğunu ifade etmektedir. ${ }^{86}$ Corti ise Çerkeş bölgesine odaklanmışsa da sınırı Karabük bölgesine kadar genişletmek istediği görülmektedir. ${ }^{87}$

Tum(m)ana Ülkesi'nin lokalizasyonu için ise pek çok araştırmacı Domanitis'i işaret etmektedir. ${ }^{88}$ Dominitis'in yeri tam olarak bilinmiyor olsa da Strabon'un anlatımından dolayı Olgassys Dağları (Ilgaz Dağları =Kaššu?) eteklerinde olduğu düşünülmektedir. ${ }^{89} \mathrm{Bu}$ bölge günümüzde kabaca Kastamonu ve çevresi ile ilişkilendirilebilir. ${ }^{90}$ Matthews ve Glatz ise bölgede

80 Roger Matthews, Claudia Glatz, "The Historical Geography of North-central Anatolia in the Hittite Period: Texts and Archaeology in Concert", Anatolian Studies 59 (2009): 51 vd.

81 Ertem, Hitit Devletinin İki Eyaleti, 13.

82 Ünal, Hititler Devrinde Anadolu II, 54.

83 Jak Yakar, Ali Dinçol, "Remarks on the Historical Geography of north-central Anatolia during the pre Hittite and Hittite periods", Tel Aviv 1 (1974): 85 vd.

84 Philo H. J. Houwink ten Cate, "Mursili's North-Western Campaigns - A Commentary", Anatolica 1 (1967): 46; Theo van den Hout, "Pala, Palaer, Palaisch", Reallexikon der Assyriologie 10 (2003-2005): 191.

85 Matthews, Glatz, "The Historical Geography of North-central Anatolia in the Hittite Period", 64-65.

86 Forlanini, "Les Routes du Palâ", 54-56.

87 Carlo Corti, "The North: Hanhana, Hattena, Ištahara, Hakpiš, Nerik, Zalpuwa, Tummana, Pala and the Hulana River Land", Mark Weeden, Lee Z. Ulmann (ed.) Hittite Landscape and Geography (Leiden: Brill, 2017): 234.

88 Emil Forrer, "Tummana", Reallexikon der Assyriologie 1/5 (1931): 392 vd; Albrecht Goetze, "Critical Review of J. Garstang, O. R. Gurney, 1959 'The Geography of the Hittite Empire', Journal of Cuneiform Studies 14 (1960): 44 vd; H. Gustav Güterbock, "Review of J. Garstang, O. R. Gurney 1959 'The North-Central Area of Hittite Anatolia"' Journal of Near Eastern Studies 20 (1961), 95; von Schuler, Die Kaskäer, 13; Houwink ten Cate, "Mursili's North-Western Campaigns - A Commentary", 45 vd; James G. Macqueen, "Geography and History in Western Asia Minor in the Second Millennium B.C.", Anatolian Studies 18 (1968): $169 \mathrm{vd}$.

89 Strab. XII. 3. 40.

90 Ertem, Hitit Devletinin İki Eyaleti, 13, 18, 19; Ünal, Hititler Devrinde Anadolu II, 54. 
geçekleştirdikleri yüzey araştırmalarında MÖ. 2. binyıla ait verilere rastlanmamış olması sebebiyle Tum(m)ana'nın daha güneyde olabileceğini düşünmektedirler. ${ }^{91}$

Söz konusu lokalizasyon önerilerine genel olarak bakıldığında; Pala Ülkesi'nin, Tum(m)ana'ya oranla daha batıda aranmış olduğu ve son dönem araştırmalarıyla da, Karabük ve Zonguldak'taki Gökçebey ilçesindeki, Filyos (Billaios) ve Devrek (Ladon) Nehirlerinin kuzeyine dek uzanan coğrafyaya işaret edildiği görülmektedir. ${ }^{92}$ Ayrıca bahsi geçen bölgenin Antik Dönem'de Tios Territoryumu'nda yer aldığ 1 da bilinmektedir ki ${ }^{93}$ Tios adının, Pala Güneş Tanrısı Tiyaz'dan (Luw. Tiwaz, Hit. šiwat-) ${ }^{94}$ gelmiş olabileceği de düşünüldüğünde, ${ }^{95}$ bahsi geçen coğrafyanın Pala Ülkesi olarak anılması oldukça kuvvetli bir varsayım olarak karşımıza çıkmaktadır. Son olarak, İnönü Mağarası'nın konumu ile bölgenin oldukça yakın oluşu, Pala Ülkesi'nin tarihi ve tarihi coğrafyasına odaklanma gerekliliği doğurmaktadır.

Pala ve Tum(m)ana Ülkeleri, Hitit kaynaklarında ilk kez I. Šuppiluliuma Dönemi'nde karşımıza çıkmaktadır. ${ }^{96}$ II. Muršili'nin annallerindeki bilgilerden, I. Šuppiluliuma'nın kardeşi “Muhafızların Başı” Zida'nın oğlu Hutupiyanza'yı, Pala Ülkesi'ne idareci olarak atadığı anlaşılmaktadır. Hutupiyanza bu görevi II. Muršili Dönemi'de de sürdürerek, II. Muršili’nin gönderdiği çeşitli desteklerle, 20 yil boyunca Pala Ülkesi'ni savunmuştur. ${ }^{97}$ Söz konusu bu metin konumuzca oldukça önemli olduğundan ilgili bölümün çevirisini tam olarak verilmiştir:

91 Matthews, Glatz, "The Historical Geography of North-central Anatolia in the Hittite Period", 64.

92 Massimo Forlanini, "Les Routes du Palâ", Michel Mazoyer, Sydney Hervé Aufrère De Hattuša à Memphis. Jacques Freu in honorem (Paris: L'Harmattan, 2013), 56; Corti, “The North: Hanhana, Hattena, Ištahara, Hakpiš, Nerik, Zalpuwa, Tummana, Pala and the Hulana River Land", 234.

93 E. Nalan Akyürek-Şahin, Sadi Uyar, “Tios Teritoryumu'ndan (Doğu Bithynia) Yeni Bir Kurşun Ağırlık”, Eskiçağ Yazıları 1 (2012): 157.

94 O. Robert Gurney, Some Aspects of Hittite Religion, (Oxford: Oxford University Press, 1977), 10; Ilya Yakubovich, "Were Hittite Kings Divinely Anointed? A Palaic Invocation to The SunGod and Its Significance for Hittite Religion", Journal of Ancient Near Eastern Religions 5 (2006): 107-108; Karl Strobel, "Altphrygische Religion und Königsideologie-Eine weitere Brücke zur hethitischen Großreichszeit?”, Colloquium Anatolicum IX (2010): 32.

95 Manfred Hutter, "Die Kontinuitat des Palaischen Sonnengottes Tiyaz in Phrygien", R. Rollinger, B. Truschnegg (hg.), Altertum und Mittelmeer-raum: Die antike Welt diesseits und jenseits der Levante. Festschrift fur Peter W. Haider zum 60. Geburtstag (Stuttgart: F. Steiner, 2006), 86.

96 Ertem, Hitit Devletinin İki Eyaleti, 8; Michele Cammarosano, "Kaššu, King of Tummanna: Bo 91/944 And L. 73 'AUDIRE' (Tab. I)”, Orientalia 85/1 (2016): 82.

97 Ertem, Hitit Devletinin İki Eyaleti, 56-60; Leyla Murat, Anadolu’da Kaškalar, (Ankara: Hel Yayıncılık, 2016), 79. 
Çeviri" 8-33 "Babam Hurri Ülkesindeyken, bu zaman boyunca Hurri Ülkeleriyle savaştı̆̆ (için), o geç kaldı. Sonra Kaška şehrinden pek çok düşman ortalı̆̆ karıştırdl. Ve (onlar) Hatti Ülkesi'ne (topraklarına) zarar verdiler. Ve bir kisım ülkeyi yok ettiler (ve bir bölümünde) oturdular. Ve ona sahip oldular. Ve Tummanna Ülkesi Babama sadık kaldl. Ve Tummanna şehrine bundan sonra müstahkem kentler inşa edildi. Ve onları Kaška kenti adamlarl yok etti. Bundan sonra orada oturdular. Ama Hutupiyanza Babamın kardeşi olan, kral oğlu "Muhafizların Başı” Zida'nın oğlu Hutupiyanza'yı Babam Pala Ülkesi'ne görevlendirdi. Fakat Pala Ülkesi ise hiçbir şekilde korunan (bir) ülke değildi. Tahkim edilmiş kentin gerisinde destek bir yer yoktu. Ülke aşağlda/yerde/alttaydı. ${ }^{99}$ Ama Hutupiyanza Pala Ülkesi’ni korudu. Ama emrinde bir ordu yoktu. Ve dağların içine sı̆̆ınacak yerler yaptı. Ve nüfus az sayldaydl. (Onlarl oraya) alıp götürdü. Ve Pala Ülkesi'nden [Düşmana] hiçbir şey vermedi. [Ve..........................] ki o Hutupiyanza'ya (karşı) [savaşa girdi]. Ve o onları sürekli olarak yendi”.

Çeviriye bakıldığında, Kaškalıların Hatti topraklarına zarar vererek Tum(m)ana'yı işgal ettiği görülür. Metnin devamında I. Šuppiluliuma'nın Hutupiyanza'y1 Pala Ülkesi’ne görevlendirmesinin ardından Pala Ülkesi'nin coğrafyası hakkında önemli bilgiler aktarılır. Pala Ülkesi'nde yer alan kentlerin hiçbirinin herhangi bir koruması olmadığının ve tahkim edilmiş/güçlendirilmiş kentin gerisinde ise onlara yardımcı olabilecek herhangi bir destek bulunmadığının ifade edilmiş olması oldukça önemlidir. Mevcut durumdan dolayı da Pala Ülkesi, "aşağıda/yerde" şeklinde tanımlanmıştır. Bazı bilim insanları dagan- "aşă̆l, yerde, altta"100

98 KBo 5.8 Vs. II A 8-33. Pasajın çevirisi için Goetze'nin çevirisi temel alınarak tekrar yapılmıştır. Çeviri için bkz. Albrecht Goetze, Die Annalen des Mursilis, MVAeG 38, Hinrichs'sche Buchhandlung, (Leipzig: Hinrichs, 1933), 153-155; Ertem, Hitit Devletinin İki Eyaleti, 56-60; Forlanini, "Les Routes du Palâ", 46; Murat, Anadolu'da Kaškalar, 80; Corti, "The North: Hanhana, Hattena, Ištahara, Hakpiš, Nerik, Zalpuwa, Tummana, Pala and the Hulana River Land", 233.

99 Metinin 25. satırında yer alan: “... da-ga-a-an e-ša-an-ta-at KUR-e e-eř-ta” cümlesi oldukça önemlidir. Murat, bu satır1: "Düz (bir) yerde iskân edilmiş (bir) ülke idi" şeklinde çevirirken (Murat, Anadolu'da Kaškalar, 80.), Forlanini ve Corti ise, "Daha çok dizlerinin üzerinde bir ülkeydi" şeklinde çevirmiştir (Forlanini, "Les Routes du Palâ", 46; Corti, "The North: Hanhana, Hattena, Ištahara, Hakpiš, Nerik, Zalpuwa, Tummana, Pala and the Hulana River Land", 233.) Ancak çeviri kelimesi kelimesine "aşağıda oturdular ülke var oldu” şeklindedir. Yani bir önce ki cümle ile birlikte değerlendirildiğinde; "Tahkim edilmiş kentin gerisinde destek bir yer yoktu, ülke aşağıdaydı/zor durumda/güçsüz kaldı" olmalıdır. Başka bir deyişle, Pala Ülkesi Kaška saldırılarından dolayı zor durumda kalmıştır çünkü bu bölgeye böyle bir saldırının yapılabileceği öngörülememiștir. Ayrıca Hititli kâtipler düz ya da ovalık bir alanı tanımlamak istediklerinde pekâlâ takšatar- kelimesini kullanabiliyorlardı (Ahmet Ünal, Hititçe Çok Dilli El Sözlügü II (N-Z), (Hamburg: Verlag Dr. Kovac, 2007), 669.)

100 Ünal, Hititçe Çok Dilli El Sözlüğü II (N-Z), 667. 
kelimesinden dolayı bu satırların Pala Ülkesi’nin coğrafyası ile alakalı olabileceğini düşünerek, Pala Ülkesi'ni düzlük ve ovalık yerde aranması gerektiğini ifade etmişlerdir. Ancak tarafımızca bu ve öncesindeki ifade, Pala Ülkesi'nin, Hatti için tehdit olmadığı ve Kaška gibi bir düșmanın da daha evvel Pala'ya dek ulaşmamış olması gibi nedenlerden dolayı, özel bir korumaya ${ }^{101}$ gerek görülmemiş/önemsenmemiş bir yer olarak tanımlandığını düşündürmektedir. Bölgenin tahkim edilmemiş olmasının üzerine vurgu yapılıyor olması, akla Hitit propagandasını getirse de "bölgeye müstahkem şehirler inşa ettirdik ve Hatti Ülkesi burayı kuvvetlendirdi" şeklinde bir ifadenin pasajda yer almayışından amacın bu olmadığı anlaşılmaktadır. Sonrasında Hutupiyanza'nın nüfusu az olan bu halkı koruyarak onlara dağlarda sığınacak yerler yapmış olması ise etrafının dağlık olması gerekliliğini göstermektedir ki ${ }^{102}$ sadece bu söylem bile Pala Ülkesi'nin ovalık bir yerde aranmaması gerekliliğ̈ini doğurmaktadır.

II. Muršili Dönemi'ndeki olaylara bakıldığında, 5. yılında Kaškaların, Hitit hâkimiyetinde olan Ašharpaya Dağı'nı ele geçirerek Pala Ülkesi'nin yollarını kesmesi üzerine, II. Muršili bölgeyi kontrol altına almıştır. ${ }^{103}$ Ašharpaya Dağı'nın Pala Ülkesi'ne giden yol üzerinde olmasından dolayı lokalizasyonu son derece önemlidir. Ertem, Ašharpaya Dağı'nı İnegöl Dağ1 ile, ${ }^{104}$ Matthews-Glatz ise İdris Dağı ile identifiye etmek istemiştir. ${ }^{105}$ Söz konusu bu anlatıma daha çok anlam yüklemeye çalışanlar ise Pala'nın Hatti Ülkesi ile ortak bir sınıra sahip olabileceklerini düşünmektedirler. ${ }^{106}$

II. Muršili’nin 9. yılında, Pala Ülkesi’nde yer aldığı bilinen Wašulana kenti, Pala'nın yöneticisi konumundaki Hutupiyanza'ya karşı ayaklanır. Bu

${ }^{101}$ I. Šuppiluliuma Dönemi’nde Tum(m)ana Ülkesi’nei Kaška tehlikesine karşı önlem amaçlı garnizonlar kurduğu bilinmektedir (Murat, "Hitit Dünyasında Gaşgaların Yeri”, 441; van den Hout, "Hitit Krallığı ve İmparatorluğu'nun Kısa Tarihi”, 30).

102 Pala Ülkesi'nin oldukça dağlık bir coğrafya olduğu bilinmektedir. Pala Ülkesi'nde olduğu düşünülen dağlar, ülkeye ulaşımı da sağlayan Ašharpaya Dağı ile Pirpirra Dağı'dır (KUB 60.117) (Corti, "The North: Hanhana, Hattena, Ištahara, Hakpiš, Nerik, Zalpuwa, Tummana, Pala and the Hulana River Land", 233).

${ }_{103}$ KBo 3.4 Rs. III 39-46; Goetze, Die Annalen des Mursilis, 76-79.

${ }^{104}$ Ertem, Hitit Devletinin İki Eyaleti, 13.

${ }^{105}$ Matthews, Glatz, "The Historical Geography of North-central Anatolia in the Hittite Period", 62.

${ }^{106} \mathrm{Bu}$ fikir, II. Hattušili’nin kral oğullarını sadece Hatti Ülkesi'ne yakın ülkelerde görevlendirmesi sebep gösterilerek ortaya atılmış ve bu bağlamda Pala'nın da Hatti Ülkesi'ne komşu olabileceği ileri sürülmüştür (Goetze, Die Annalen des Mursilis, 77; von Schuler, Die Kaskäer, 46). Ancak prenslerin vali olarak gönderilecekleri yerlerin, konumlarının merkeze yakınlıklarından ziyade, stratejik açıdan önemli olmalarına göre (Emar, Halpa, Kargamış, Alalah vb.) seçildikleri unutulmamalıdır (Tayfun Bilgin, Officials and Administration in the Hittite World, (Berlin/Boston: De Gruyter, 2018), 37-76). 
nedenle II. Muršili “Şarap Büyüğü” Nuwanza'yı beraberindeki destek kuvvetle birlikte bölgeye yollar ve Hutupiyanza bu destekle birlikte Wašulana kentini yenerek kenti yakarlar. Elde ettikleri ganimetleri (esir, koyun ve sığırları) ise Hattuša'ya götürürler. ${ }^{107}$ Forlanini Wašulana'nın, Safranbolu'nun kuzeyinde ya da batısında yer alabileceğini düşünmektedir. ${ }^{108}$

II. Muršili'nin 16. yılına bakıldığında ise, bölge hakkında daha geniş bilgiler edinmek mümkündür. II. Muršili, Kaškalarca işgal edilen Tum(m)ana Ülkesi üzerine yürür. Metne göre hedeflerinden biri ise Šapidduwa ${ }^{109}$ kentidir. II. Muršili ilk olarak ordusunu farklı bir düşman olan Pittapara üzerine sürer ve güneş battıktan sonra da Pitaggalli ile karşılaşmak üzere Šapidduwa'ya gelir. 9000 kişilik bir ordusu bulunmasına karşın Muršili'ye karşı duramaz ve Elluriya Dağı'na kaçar. Muršili'nin ordusunun bir kısmı Pitaggalli'yi Dahara Irmak'ına dek kovalar. Ardından Muršili ganimetleri Altana kentinde topladıktan sonra Kaššu Dağı'na ${ }^{110}$ yürür ve ardından tekrar Pittaggalli'nin peşine düşer. Metnin bundan sonrası kırık olsa da Muršili’nin zafer elde ettiği düşünülmektedir. ${ }^{11}$

$\mathrm{Bu}$ seferin ardından II. Muršili’nin yönünü Kalašma’ya dönmesi bizim için önemlidir. Zira Kalašma araştırmacıların büyük çoğunluğu tarafından Hatti Ülkesi'nin kuzeybatısında yer aldığı kabul edilen bir yerdir. ${ }^{112}$ Ve halen tartışmalı olmakla birlikte Starke, Kalašma Ülkesi'ni GeredeSafranbolu civarına, ${ }^{113}$ Forlanini ise Bolu'ya lokalize etmektedir. ${ }^{114}$ Ayrıca

107 Goetze, Die Annalen des Mursilis, 106 vd.

108 Massimo Forlanini, "L'Anatolia nordoccidentale nell'impero eteo", Studi Micenei ed EgeoAnatolici 18 (1977): 219.

${ }^{109} \mathrm{Bu}$ kentin tam lokalizasyonu henüz bilinmiyor olsa da (Del Monte, Tischler, Die Orts-und Gewässernamender hethitische Texte, 349; Giuseppe Del Monte, Die Orts- und Gewässernamen der hethitischen Texte - Supplement, (Wiesbaden: Ludwig Reichert, 1992), 140) metinlerden yola çıkılarak Gökırmak vadisinde olabileceği ileri sürülmüştür (Corti, "The North: Hanhana, Hattena, Ištahara, Hakpiš, Nerik, Zalpuwa, Tummana, Pala and the Hulana River Land", 230).

${ }^{110}$ Çoğunlukla Olgassys=Ilgaz Dağları şeklide lokalize ediliyor olsa da henüz kesin değildir (Del Monte, Tischler, Die Orts-und Gewässernamender hethitische Texte, 195 vd.; Del Monte, Die Orts- und Gewässernamen der hethitischen Texte - Supplement, 74). Ancak Tum(m)ana Ülkesi içinde yer aldığı ifade edilmektedir (Cammarosano, "Kaššu, King of Tummanna: Bo 91/944 And L. 73 'AUDIRE' (Tab. I)”, 82).

${ }^{111}$ Kırık bir kontextte Fırtına Tanrısı'nın kralın elini tuttuğu söyleminden yola çıkılarak zafer kazandığı düşünülmektedir (KBo 5.8 III 41 vdd.; Goetze, Die Annalen des Mursilis, 160 vd; Metin Alparslan, II. Murşili Dönemi, İstanbul Üniversitesi, Hititoloji Bilim Dalı, Yayınlanmamış Doktora Tezi, (İstanbul: 2006), 93.

112 Del Monte, Tischler, Die Orts-und Gewässernamender hethitische Texte, 163 vd.; Del Monte, Die Orts- und Gewässernamen der hethitischen Texte - Supplement, 60.

113 Frank Starke, "Hitit İmparatorluğu'nun Yapısı", W. Jacob (ed.), Hititler, Bin Tanrllı Halk, (Bonn: Kunst-und Ausstellungshalle der Bundesrepublik Deutschland, 2002), Harita.

114 Forlanini, "Les Routes du Palâ", 54. 
Hutupiyanza'nın mektuplarından birinde Pala Ülkesi'nde buzlanma olduğu öğrenilmektedir. Bu bilgiden hareketle hem bölgenin hem de mevcut askeri birliklerin mevcut durumdan olumsuz etkilenmiş olduğu anlaşılmaktadır. II. Muršili'nin, Anadolu'nun batısına yönelik seferlerinden birini bu nedenle iptal ettiği de düşünülmektedir. ${ }^{115}$ Belki de bu nedenle Hutupiyanza'nın II. Muršili'nin kaçıncı yılında olduğu tam olarak bilinmeyen bir metinde isyan eden Kalašma Ülkesi'ne bizzat müdahale ederek Hatti Ülkesi'ne tekrar bağladığı anlatılmaktadır. Bu süreçte Hutupiyanza artık sadece Pala'nın değil, Tum(m)ana'nın da idarecisi olarak görülmektedir. ${ }^{116}$ Mevcut bilgiler, bize Tum(m)ana, Pala ve Kalašma Ülkelerinin birbirlerine olan yakınlıkları hakkında da fikir vermektedir. II. Muwatalli, Pala Ülkesi'nin idaresini, kardeşi II. Hattušili’ye vermiştir. ${ }^{117}$ II. Hattušili otobiyografisinde bu olayı aktarırken "bu issız toprakları" kendi başına yeniden inşa ettiğinden ve yeniden Hatti toprağ 1 haline getirdiğinden bahsetmektedir. ${ }^{118}$ II. Hattušili son olarak KUB 23.127 no'lu metinde, Pala ve Tum(m)ana'nın idaresini IV. Tuthaliya'ya devretmektedir. ${ }^{119}$ II. Hattušili'nin vermiş olduğu bu bilginin ardından Hitit İmparatorluğu'nun çöküşüne dek Pala Ülkesi hakkında yazılı metinlerden herhangi bir bilgi elde edilememektedir. Bu nedenle de Pala Ülkesi'nin Hatti Ülkesi'ne olan bağlılığının bozulmadığı düşünülmektedir. ${ }^{120}$

\section{Sonuç}

Kdz. Ereğli ilçesinin kıyıdan yaklaşık $30 \mathrm{~km}$ güneydoğusunda bulunan İnönü Mağarası, bölgenin gür ormanlarla kapl1, engebeli coğrafyası içerisinde yer alan küçük sayılabilecek bir mağara yerleşmesidir. Bölgede, daha önceki yıllarda Yassıkaya Mevki dışında sistematik olarak araştırılmış yerleşim yerlerinin bulunmayışı, İnönü Mağarası kazılarının önemini

\footnotetext{
${ }^{115}$ Ahmet Ünal, Hititler Devrinde Anadolu III, (İstanbul: Arkeoloji ve Sanat Yayınları, 2005), 49.

${ }^{116}$ KBo 2.5 IV 18, 27; Goetze, Die Annalen des Mursilis, $192 \mathrm{vd}$

${ }^{117}$ KUB 1.1. Vs. II 55-63 (=KBo 3.6 +KUB 1.7) II. Hattušili'nin idaresine birakılan diğer yerler; İ̌hupitta, Marišta, Hiššašhapa, Katapa, Hanhana, Darahna, Hattena, Durmitta, Tum(m)ana, Gaššiia, Šappa ve Hulana Nehri Ülkesi'dir. Transkripsiyon ve tercüme için; Albrecht Goetze, Hattušiliš. Der Bericht über seine Thronbesteigung nebst den Paralleltexten, (Leipzig: J. C. Hinrichs, 1925), 59; Ertem, Hitit Devletinin Iki Eyaleti, 8; Meltem Doğan-Alparslan, Hitit Kralı II. Muwatalli: Kişiliği ve İcraatı Filolojik Belgeler Işı̆ğında (İstanbul: Türk Eskiçağ Bilimleri Enstitüsü Yayınları, 2012), 73 vd.; Massimo Forlanini, "The Central Provinces of Hatti: an Updating", Eothen 16 (2008): 167; Özlem Sir-Gavaz, "Hititçe Metinlerde Geçen KUR IDHulana-/KUR IDSíG 'Yün Nehri Ülkesi' Üzerine Yeni Bir Değerlendirme”, Belleten LXXX-288 (2016): 358, 359.

${ }^{118}$ II. Hattušili'nin Otobiyografisi, II 55-68.

119 Goetze, "Bemerkungen zu dem hethitschen Text AO 9608". 48 vd.

${ }^{120}$ Ertem, Hitit Devletinin İki Eyaleti, 8.
} 
arttırmaktadır. İnönü Mağarası'nda 2017 yılında itibaren sürdürülen kazılarda Batı Karadeniz Bölgesi kültürlerini anlamamızı sağlayacak çok sayıda veri elde edilmiştir. $\mathrm{Bu}$ veriler içinde mağaranın III. yapı katında bulunan ve Geç Tunç Çăğ'na tarihlenen bulgular ayrıcalıklı bir yere sahiptir. Söz konusu bulgular daha önce hakkında çok fazla bilgi sahibi olmadığımız Batı Karadeniz Bölgesi'nin Geç Tunç Çağı kültürel yapısı ve bu dönemde Anadolu'da merkezi bir güç olan Hititler ile bölge kültürlerinin ilişkisi hakkında kayda değer ipuçları sunmuştur. Uzun yıllar boyunca arkeolojik araştırmalardan yoksun kalan bölgede, çeşitli yollarla elde edilen ve satın alma yoluyla bölge müzelerine kazandırılan buluntular, Geç Tunç Çağı'na ilişkin heyecan verici bulgular olmuştur. Söz konusu buluntuların Hitit şehirlerinde ele geçen bulguları aratmayacak nitelikte oluşu, bunların Hitit metinlerinde adı geçen Kaşkalarla iliş̧isini akıllara getirmiştir. Diğer taraftan bazı araştırmacılar da bu bulguların yine Hitit metinlerinden adını bildiğimiz Pala ve Tum(m)ana ülkelerinin lokalizasyonu konusunda ipuçları olabileceğini ifade etmiştir.

1950'li yılardan itibaren Batı Karadeniz bölgesinde Zonguldak, Karabük, Bartın, Bolu ve Kastamonu'nun batısında kalan bölgede yapılan araştırmalarda, Geç Tunç Çağı'na ilişkin az sayıda bulgu elde edildiğine ya da bulguların kıyıya doğru giderek azaldığına vurgu yapılmıştır (Fig. 1). Bu çalışmalardan birini yürüten, C. A. Burney'in bölgede, yaptı̆̆ı yüzey araştırmalarında Karabük-Eflani civarında Geç Tunç Çă̆ı'na tarihlenen az sayıda seramiğin elde edildiği bildirilmiştir. ${ }^{121}$ Bunun yanında A. Ünal, Devrez Çayı kenarında bulunan Salman Höyük'ün, Batı Karadeniz Bölgesi'nin Geç Tunç Çağı kültürlerinin anlaşılması konusunda önemli bir potansiyele sahip olduğu üzerinde durmaktadır. ${ }^{122}$ Yanı sıra yine bölgede bulunan Semercitepe (Eflani) ve Taşköprü Yolu höyüklerinin de bölgenin önemli Geç Tunç Çağı yerleşimleri arasında olduğu düşünülmektedir. ${ }^{123}$ Bölgenin iç kesimlerinden kıyıya doğru ilerledikçe Karabük hattından itibaren dağlık ve yoğun bitki örtüsüyle kaplı coğrafyada Geç Tunç Çă̆ı'na ilişkin veri sunan höyüklerin ve buluntu alanlarının giderek azaldığı dikkati çekmektedir. Bu durumun sebeplerinin başında yukarıda ifade edildiği gibi bölgenin zor coğrafi koşulları gelmektedir. Söz konusu bölge höyükleşme için

${ }^{121}$ Charles A. Burney, "Northern Anatolia Before Classical Times", Anatolian Studies VI (1956): 192.

122 Ahmet Ünal, "A Hittite Mycenaean Type B Sword from the Vicinity of Kastamonu, Northwest Turkey", Bulletin of the Middle Eastern Culture Center in Japan XI (1999): 209.

${ }^{123}$ Kutlu Emre, Aykut Çınaroğlu, "A Group of Metal Vessels from Kınık-Kastamonu”, M. J. Mellink, E. Porada, T. Özgüç (ed.), Aspects of Art and Iconography: Anatolia and its Neighbors. Studies in Honor of Nimet Özgüç, (Ankara: Türk Tarih Kurumu Basımevi, 1993), 703. 
uygun olmadığ gibi, erozyon ve yoğun bitki örtüsü sebebiyle yüzey buluntusu takibi açısından büyük dezavantajlara sahiptir. Bu nedenle bölgede yapılan araştırmalarda, mağara, kaya altı sığınağ 1 ve kısmen yamaç yerleşimlerinin daha iyi bir şekilde tespit edildiği görülmektedir.

Batı Karadeniz Bölgesi'nde yürütülen kapsamlı yüzey araştırmalarından biri olan Cide-Şenpazar yüzey araştırmalarında tespit edilen mağara ve kayaaltı sığınaklarında, Geç Tunç Çağı'na ilişkin sınırlı sayıda buluntu elde edilebilmiştir. Yine bu bölgede, Geç Tunç Çağı'na tarihlenen ve doğrudan Hitit kültürü ile bağlantı kurmamızı sağlayan bir kılıç KastamonuPınarbaşı Mevkii, Buz Mağarası'nda ele geçmiştir. ${ }^{24}$ Mağarada yapılan araştırmalarda başka bir bulguya rastlanılmadığı ifade edilmiştir. Çankırı, Kastamonu ve Karabük illeri arasında kalan sahada R. Matthews ve ekibi tarafından yapılan araştırmalarda da az da olsa Geç Tunç Çağı'na tarihlenebilecek bulguların elde edildiğinden söz edilmiştir. ${ }^{125}$ Bölgede yürütülen yüzey araştırmalarında elde edilen kısıtlı verilerin yanında önemli bir buluntu topluluğu Kastamonu-Kınık'ta ele geçmiştir. ${ }^{126}$ Fakat burada Delibeyoğlu Sirtı ören yerinde yapılan kazılarda, buluntularla çağdaş bir yerleşim tespit edilememiştir. Bölgenin güneyinde ise, Bolu ili menşeili olduğu düşünülen bir kolcuklu balta, K. Bittel ${ }^{127}$ tarafindan ve bir kılıç ve mızrak ucu da A. Müller-Karpe ${ }^{128}$ tarafından yayınlanmıştır. Bolu ili sınırları içinde dikkat çeken bir başka buluntu grubu Seben ilçesi, Korucuk Mevkii'nde ele geçmiştir. T. Yıldırım tarafından detaylı bir yayını yapılan, Geç Tunç Çağı'na ait metalden yapılmış çanaklar ve çeşitli tipte silahlar oldukça dikkat çekicidir. ${ }^{129}$ Bolu-Seben, buluntularının ele geçtiği düşünülen yerde yapılan araştırmalarda da herhangi bir bulguya rastlanılmamıştır. Bolu-Seben, Kastamonu-Kınık, Kastamonu-Buz Mağarası bulguları ve Orta Karadeniz Bölgesi'nde Sinop ve Samsun müzeleri tarafından satın alınan eserler, yine benzer şekilde tesadüfen bulunmuş olan Sivas-Şarkışla ve Ordu eserleri gibi

124 Ünal, "A Hittite Mycenaean Type B Sword from the Vicinity of Kastamonu, Northwest Turkey”, 210.

${ }^{125}$ Claudia Glatz, Roger Matthews, "Anthropology of a Frontier Zone: Hittite-Kaska Relations in Late Bronze Age North-Central Anatolia”, Bulletin of the American Schools of Oriental Research 339 (2005): 59.

${ }^{126}$ Emre, Çınaroğlu, "A Group of Metal Vessels from Kınık-Kastamonu”.

${ }^{127}$ Kurt Bittel, "Neue Funde Vorklassischer Zeit aus Kleinasien", AA Beiblatt, III/IV (1934): 353, fig. 4.

${ }^{128}$ Andreas Müller-Karpe, “Anatolische Bronzeschwerter und Südosteuropa”, C. Dobiat (ed.), Festschrift für Otto-Herman Freye zum 65. Geburtstag, (Marburg: Hitzeroth, 1994), fig. $5 / 1-2$

${ }^{129}$ Tayfun Y1ldırım, "A Group of Hittite Bronze Objects from the Seben District of Bolu”, Anatolica XXVII (2001): 127. 
yerleşimle ilişkisi olmayan buluntular, ${ }^{130}$ toplu buluntu/depotfunde/findspot olarak değerlendirilmiş, bunların adak eşyaları veya kişisel sermaye olabileceği düşünülmüsstür. Bir diğer görüşe göre de bu buluntular, Kaşkaların Hitit kentlerinden ve/veya tapınaklarından yağmaladıkları ganimetler olmalıdır. ${ }^{131}$ Bölgenin daha batısında bulunan İstanbul'da Bathonea antik kentinde yapılan kazılarda da kırmızı astarlı, parlak perdahlı, Hitit kap formları ile uyumlu testi parçaları ile demir ve kurşundan yapılmış heykelcikler bulunmuş ve Eski Hitit dönemine tarihlendirilmiştir. ${ }^{132}$

İnönü Mağarası bulguları söz konusu buluntulardan farklı olarak Batı Karadeniz Bölgesi'nde sistematik kazılarda elde edilen ve tanımlı tabakalarda kontekse bağlı olarak ele geçen bulgular olarak önem taşımaktadır. Mağaranın III. tabakasında bulunan ahşap tabanlar üzerinden alınan yedi adet karbon örneğinin analizleri Kal. M.Ö. 1431-1285 ile Kal. MÖ 1295-1123 aralığını vermektedir (Fig. 9). Buluntuların analojik karşılaştırması da söz konusu tarihlerle oldukça uyumludur. Bu nedenle buluntuların paralel örnekleri ve tabakanın radyokarbon tarihleri dikkate alındığında İnönü Mağarası'nın, Batı Karadeniz kıyısında, Hitit çekirdek bölgesinin kuzeybatısında, küçük bir Geç Tunç Çağı yerleşimi olduğunu düşünmekteyiz. Batı Karadeniz bölgesinde, ilk kez tanımlı tabakalarda bulunan ve Geç Tunç Çă̆ı'na ait tunç boğa heykelciği, kilden yapılmış tanrı heykelciği başı (?) ve tunç silahlar bölgedeki Hitit yerleşimlerini ve Hititlerle dostane veya düşmanca ilişkileri bulunan şehirleri ve toplulukları akla getirmektedir. Bu sebeple, İnönü Mağarası Geç Tunç Çağı yerleşiminin bahsi geçen şehir ve topluluklarla ilişkisi de kaçınılmaz olarak sorgulanmaktadır.

İnönü Mağarası'nın söz konusu dönemde hangi ülke sınırları içerisinde kaldığını anlamak için Pala ve Kaška ülkelerinin lokalizasyonlarını belirlemek gerekmektedir. Kaškalar ile Hititler arasında düşmanca bir ilişki olduğu, Kaškaların Hatti toprakları üzerinde neredeyse sürekli bir tehlike haline geldiği anlaşılmaktadır. Hitit ordusu, Kaška tehlikesini engellemek için gerek bölgeye garnizon kurarak gerek seferler düzenleyerek gerekse de çeşitli nüfus aktarımları ile bölgeyi koruma altına almaya çalışmıştır. Kaškaların bu savaşçı kimlikleri, yaşadıkları coğrafya ve kabileler halindeki yaşayış şekilleri, geçici/mevsimlik konutları tercih edebileceklerini düşündürmektedir. $\mathrm{Bu}$ nedenle de mimarilerinde, halen bölgede sıklıkla tercih edilen ve günümüze

${ }^{130}$ Kurt Bittel, Beitrag zur Kenntnis hethitischer Bildkunst, (Heidelberg: Winter, 1976),19; Stefan Przeworski, "Der Grottenfund von Ordu", Archiv Orientalni 7 (1935).

131 Ünal, Hititler Devrinde Anadolu II, 48; Murat, Anadolu'da Kaškalar.

132 Şengül Aydıngün, Haldun Aydıngün, “İstanbul'da Hitit İzleri”, B. Gür, S. Dalkılıç (ed.), Anadolu Prehistoryasına Adanmış Bir Yaşam, Jak Yakar'a Armağan, (Ankara: Bilgin Kültür Sanat Yayınları, 2020), 21. 
ulaşması oldukça güç olan ahşap materyaller kullanmış olmaları oldukça muhtemeldir. Olasılıkla bölgede, Kaškalara dair bir yerleşim yerinin henüz tespit edilememiş olmasının nedeni de budur. Tüm bunlara ilaveten, Zonguldak ve çevresinin Kaškalar tarafindan bir yerleşim yeri olarak kullanılmış olduğuna dair filolojik bir verinin olmayışı ve Kaška'nın yerel üretimlerinin bilinmiyor oluşu da kesin bir yargıya varmamızı engellemektedir.

Diğer yandan son dönem çalışmalarında, Zonguldak ve yakın çevresinin, Pala Ülkesi içinde değerlendirilmesi, bu coğrafyada yer alan Tios antik kentinin adının Pala Güneş Tanrısı'nın adından gelmiş olabileceğinin ifade edilmiş olması, Pala Ülkesi'nin de aynı Zonguldak ve çevresi gibi dağlık oluşu, söz konusu bölgeyi Pala Ülkesi olarak görmeyi mümkün kılmaktadır. $\mathrm{Bu}$ varsayımı destekleyen en önemli veri ise, I. Šuppiluliuma döneminde Pala Ülkesi'nin idareciliğini yapan Hutupiyanza'nın Pala halkını korumak adına, onlara mağaralarda sığınaklar yapmış olmasıdır. Hutupiyanza'nın uzun yıllar Pala Ülkesi'nin koruyuculuğunu üstlenmiş olması ve oldukça başarılı olduğunun aktarılması ise yapmış olduğu planın işe yaradığının bir göstergesidir. Elbette bölgenin Pala Ülkesi olarak anılması düşüncesi filolojik verilerle destekleniyor olsa da arkeolojik veriler son derece önemlidir. $\mathrm{Bu}$ noktada İnönü Mağarası'nda ele geçen Hitit tasvir sanatına uygun eserler ve mimari unsurlar oldukça önemli katkılar sunmaktadır. Ek olarak, İnönü Mağarası kazılarından alınan radyokarbon tarihlerinin (Kal. M.Ö. 1431-1285 ile Kal. MÖ 1295-1123) (Fig. 9) filolojik belgelerin tarih aralıkları ile örtüşüyor olması varsayımlarımızı daha da kuvvetlendirmektedir. Elbette ki ilerleyen yıllarda yapılacak yeni çalışmalar, konu hakkında daha kesin sonuçlara ulaşmamızı sağlayacaktır.

\section{Katkı Belirtme}

Kültür ve Turizm Bakanlığı, Kültür Varlıkları ve Müzeler Genel Müdürlüğü, Zonguldak Valiliği, Kdz. Ereğli Kaymakamlığı, Kdz. Ereğli Belediyesi ve Zonguldak Bülent Ecevit Üniversitesi Rektörlüğü İnönü Mağarası kazılarına kurumsal ve maddi destek sağlamıştır. Prof. Dr. Ünsal Yalçın ve Dr. Öğr. Üyesi Ümit Güder P-XRF cihazı ile analizler yapmıştır. Prof. Dr. Aygül Süel Ortaköy bulguları ile ilgili bilgileri bizlerle paylaşmıştır. Prof. Dr. Mustafa Sözen küçük buluntuların fotoğrafinı çekmiştir. Arkeolog Burak Kader ve Ümmügülsüm Uğurlu çizim ve fotoğraflarla levhaların oluşmasını sağlamıştır. Ayrıca yazarlardan $H$. Ekmen'in çalışmaları Zonguldak Bülent Ecevit Üniversitesi (BAP-2020-91149634-01) tarafindan, F. G. Ekmen'in çalışmaları ise TUBİTAK 2219 Yurt Dışı Doktora Sonrası Araştırma Bursu (2018-2) tarafından desteklenmiştir. Tüm kurum ve kişilere içten teşekkürlerimizi sunarız. 


\section{KAYNAKÇA}

Akyürek-Şahin, Eda Nalan ve Uyar, Sadi. “Tios Teritoryumu'ndan (Doğu Bithynia) Yeni Bir Kurşun Ağırlık”, Eskiçağ Yazıları 1 (2012): 157-174.

Alp, Sedat. Hitit Çă̆ında Anadolu Çivi Yazılı ve Hiyeroglif Yazılı Kaynaklar. Ankara: Tübitak Yayınları, 2000.

Alkım, Uluğ Bahadır, Alkım Handan, Bilgi Önder. İkiztepe II, Üçüncü, Dördüncü, Beşinci, Altıncı, Yedinci Dönem Kazıları (1976-1980). Ankara: Türk Tarih Kurumu Yayınları, 2003.

Alparslan, Metin. II. Murşili Dönemi. İstanbul Üniversitesi, Hititoloji Bilim Dalı, Yayınlanmamış Doktora Tezi, İstanbul, 2006.

Anlağan, Çetin, Anlağan Tanju, Günsenin Yeşim, Yılmaz Hülya, Akalın Şebnem. Sadberk Hanım Müzesi. İstanbul: Sadberk Hanım Müzesi, 1995.

Arık, Remzi Oğuz. Alacahöyük Hafriyatı 1935'deki Çalışmalara ve Keşiflere Ait ilk Rapor. Ankara: Türk Tarih Kurumu Yayınları, 1937.

Aydıngün, Şengül ve Aydıngün, Haldun. "İstanbul'da Hitit İzleri”, ed. B. Gür, S. Dalkılıç, Anadolu Prehistoryasına Adanmış Bir Yaşam, Jak Yakar'a Armağan. 21-34, Ankara, 2020.

Bilgi, Önder. Anadolu'da İnsan Görüntüleri, Klasik Çă̆ Öncesi. İstanbul: Aygaz, 2012.

Bilgin, Tayfun. Officials and Administration in the Hittite World. Berlin/Boston: De Gruyter, 2018.

Bittel, Kurt. "Neue Funde Vorklassischer Zeit aus Kleinasien", AA Beiblatt, III/IV (1934): 349-364.

Bittel, Kurt. Boğazköy I, Die Kleinfunde der Grabungen 1906-1912. Leipzig: J. C. Hinrichs, 1937.

Bittel, Kurt. Beitrag zur Kenntnis hethitischer Bildkunst. Heidelberg: Winter, 1976.

Bittel, Kurt, Beran Thomas, Bossert Eva Maria, Fischer Franz, Otten Heinrich "Vorläufiger Bericht über die Ausgrabungen in Boğazköy im Jahre 1956", Mitteilungen der Deutschen Orient-gesellschaft 89 (1957): Beiheft.

Boehmer, Rainer Michael. Die Kleinfunde von Boğazköy. Berlin: Mann, 1972.

Bryce, Trevor Robert. "The Boundaries of Hatti and Hittite Border Policy", Tel-Aviv, Vol 13-14 (1986-1987): 85-102.

Burney, Charles Allen. "Northern Anatolia Before Classical Times", Anatolian Studies VI (1956), 179-203.

Cammarosano, Michele. "Kaššu, King of Tummanna: Bo 91/944 And L. 73 'AUDIRE' (Tab. I)", Orientalia 85/1 (2016): 79-83.

Cavaignac, Eugène. "L'extension de la zone Gasgas a I Quest", Revue Hittite et Asianique 4. Paris, 1931.

Corti, Carlo. "The North: Hanhana, Hattena, Ištahara, Hakpiš, Nerik, Zalpuwa, Tummana, Pala and the Hulana River Land", ed. Mark Weeden, Lee Z. Ulmann, Hittite Landscape and Geography. 219-238. Leiden, 2017 
De Martino, Stefano. Du Kussara a Karkemish Storia del Regno Iftira. Firenze: Logismo Editöre, 2016.

Del Monte, Giuseppe ve Tischler, Johann. Die Orts-und Gewässernamender hethitische Texte. Wiesbaden: Dr. Ludwig Reichert Verlag, 1978.

Del Monte, Giuseppe. Die Orts- und Gewässernamen der hethitischen Texte Supplement, Wiesbaden: Ludwig Reichert, 1992.

Darga, Ayşe Muhibbe. Hitit Sanatı. İstanbul: Akbank Kültür ve Sanat Kitapları, 1992.

Doğan-Alparslan, Meltem. Hitit Kralı II. Muwatalli: Kişiliği ve Ícraatı Filolojik Belgeler Işı̆̆ı̆ da. İstanbul: Türk Eskiçağ Enstitüsü Yayınları, 2012.

Dönmez, Șevket ve Dönmez, Emine Naza. “Geç Kalkolitik Çağ'dan Günümüze Orta Karadeniz Bölgesi Kıyıları Kırsal Kesiminde Geleneksel Ahşap Mimari”, ed. M. Alpaslan, M. Doğan-Alpaslan, H. Peker, Vita, Belkıs Dinçol ve Ali Dinçol'a Armağan. İstanbul, 2007. 219-236.

Ekiz, Halil Hamdi. "Çorum Müzesi’nde Bulunan Bir Hitit Tanrı Heykelciği Başı", Kubaba: Arkeoloji-Sanat Tarihi-Tarih Dergisi 7 (2006), 26-29.

Ekmen, Fadile Gülden. "İnönü Mağarası Kazıları Işı̆̆ında Kalkolitik Çă̆g'da Batı Karadeniz Bölgesi”, Tüba Ar 26 (2020): 45-64.

Ekmen, Hamza. “İnönü Mağarası'nda Bulunan Erken Tunç Çă̆ı'na Ait Sütten İkincil Ürün Üretiminde Kullanılan Bir Çömlek Üzerine Gözlemler”, e.d. H. G. Yalçın, O. Stegemeier, Metalurgica Anatolica, Festschrift für Ünsal Yalçın anlässlich seines 65. Geburtstags/Ünsal Yalçın 65. Yaşgünü Armağan Kitabl. Bochum, 2020. 77-85.

Ekmen, Hamza, Mercan Ahmet, Ekmen Fadile Gülden, Güney Ali. “İnönü Mağarası 2018 Yılı Kazı Çalışmaları" 41. Kazı Sonuçları Toplantısı, 2. Cilt (2020): 309-330.

Ekmen, Hamza, Ekmen Fadile Gülden, Güney Ali. "İnönü Cave: New Results of the Early Iron Age Culture in the Western Black Sea Region" OLBA XXVIII (2020): 35-56.

Emre, Kutlu ve Çınaroğlu, Aykut. "A Group of Metal Vessels from KınıkKastamonu", ed. M. J. Mellink, E. Porada ve T. Özgüç, Aspects of Art and Iconography: Anatolia and its Neighbors. Studies in Honor of Nimet Özgüç. Ankara, 1993. 675-713.

Erkanal, Hayat. Die Äxte und Beile des 2. Jahrtausends in Zentralanatolien. Prähistorische Bronzefunde IX-8 (1977)

Ertem, Hayri. Hitit Devletinin İki Eyaleti: Pala Tum(m)ana ile yakın çevrelerindeki Yerlerin Lokalizasyonu Üzerine Yeni Denemeler. Ankara: Ankara Üniversitesi Dil ve Tarih-Coğrafya Fakültesi Yayınları, 1980.

Ertem, Hayri. Korucutepe I, 1973-1975 Kazı Yıllarında Ele Geçen Erken Hitit-Imparatorluk Çağl Arası Buluntuları. Ankara: Türk Tarih Kurumu Yayınları, 1988.

Erzen, Afif. "Sinop Kazıları 1953 Yılı Çalışmaları", Türk Arkeoloji Dergisi 6-1 (1956): 69-72. 
Esin, Ufuk. “Tepecik Kazısı 1974”, Keban Projesi 1974-1975 Çalışmaları. 71-118. Ankara: Orta Doğu Teknik Üniversitesi Keban Projesi Yayınları, 1982.

Forlanini, Massimo. "L'Anatolia nordoccidentale nell'impero eteo", Studi Micenei ed Egeo-Anatolici 18 (1977): 197-225.

Forlanini, Massimo."The Central Provinces of Hatti: an Updating", Eothen 16 (2008): 145-188.

Forlanini, Massimo. "Les Routes du Palâ", Michel Mazoyer, Sydney Hervé ed., De Hattuša à Memphis. Jacques Freu in honorem. Paris: L'Harmattan, 2013. 43-58.

Forlanini, Massimo ve Marazzi Massimiliano. Atlante Storico del Vicino Oriente Antico 4. 3 Anatolia. Roma: L'impero Hittita, 1986.

Forrer, Emil. “Ausbeute aus den Boğazköi-Inschiften”, Mitteilungen der Deutschen Orient-gesellschaft 61 (1921).

Forrer, Emil. "Tummana", Reallexikon der Assyriologie 1/5 (1931): 392-393.

Gardiner, Alan. Geschichte des Alten Aegypten. Stuttgart: Alfred Kröner Verlag, 1965.

Garstang, John ve Gurney, Oliver Robert. The Geography of the Hitite Empire. London: British Institute of Archaeology at Ankara, 1959.

Glatz, Claudia ve Matthews, Roger. "Anthropology of a Frontier Zone: Hittite-Kaska Relations in Late Bronze Age North-Central Anatolia", Bulletin of the American Schools of Oriental Research 339 (2005): 47-65.

Goetze, Albrecht. "Kleinnasien zur Hethiterzeit, Eine geographische Untersuchung", ed. H. Bergstaesser, F. Boll, Orient und Antike, 1. Heft. Heidelberg, 1924.

Goetze, Albrecht. Hattušiliš. Der Bericht über seine Thronbesteigung nebst den Paralleltexten. Leipzig: J. C. Hinrichs, 1925.

Goetze, Albrecht. "Bemerkungen zu dem hethitschen Text AO 9608”, Revue Hittite et Asianique 1 (1930): 18-30.

Goetze, Albrecht. Die Annalen des Mursilis, MVAeG 38, Hinrichs'sche Buchhandlung, Leipzig: Hinrichs, 1933.

Goetze, Albrecht. "Critical Review of J. Garstang, O. R. Gurney, 1959 'The Geography of the Hittite Empire', Journal of Cuniform Studies 14 (1960): 43-48.

Gurney, Oliver Robert. Some Aspects of Hittite Religion. Oxford: Oxford University Press, 1977.

Güterbock, Hans Gustav. "Review of J. Garstang, O. R. Gurney 1959 'The NorthCentral Area of Hittite Anatolia"” Journal of Near Eastern Studies 20 (1961): 85-97.

Hutter, Manfred. "Die Kontinuitat des Palaischen Sonnengottes Tiyaz in Phrygien", ed. R. Rollinger, B. Truschnegg, Altertum und Mittelmeer-raum: Die antike Welt diesseits und jenseits der Levante. Festschrift fur Peter W. Haider zum 60. Geburtstag (Oriens et Occidens 12), Stuttgart, 2006. 81-88. 
Hoffner, Harry A. “Asyndeton in Hittite”, ed. D. Groddek, M. Zorman, Tabularia Hethaeorum-Hethitologische Beiträge Silvin Košak zum 65. Geburtstag. Wiesbaden, 2007. 385-399.

Houwink ten Cate, Philo, H. J. "Mursili's North-Western Campaigns - A Commentary", Anatolica 1 (1967): 44-61.

Hrozny, Bedrich. Die älteste Geschichte Vorderasiens und Indiens. 2. Auflage. Prag: Melantrich, 1943.

Koşay, Hamit Zübeyr ve Akok, Mahmut. Alaca Höyük Kazısı. Ankara: Türk Tarih Kurumu Yayınları, 1966.

Kökten, İsmail Kılıç, Özgüç Tahsin, Özgüç Nimet. "1940 ve 1941 Yılında Türk Tarih Kurumu Adına Yapılan Samsun Bölgesi Kazıları Hakkında İlk Kısa Rapor", Belleten IX/35 (1945): 361-400.

Kulakoğlu, Fikri. "A Hittite God From Kültepe" ed. Cécile Michel, Old Assyrian Studies in Memory of Paul Garelli. Leiden, 2008. 219-236.

Lloyd, Seton ve Mellaart, James. Beycesultan Vol.I. London: British Institute of Archaeology at Ankara, 1962.

Macqueen, James G. "Geography and History in Western Asia Minor in the Second Millennium B.C.”, Anatolian Studies 18 (1968): 169-185.

Matthews, Roger ve Glatz, Claudia. "The Historical Geography of North-central Anatolia in the Hittite Period: Texts and Archaeology in Concert", Anatolian Studies 59 (2009): 51-72.

Mayer, Leo Ary ve Garstang, John. Index of Hittite Names. London: Council, 1923.

Murat, Leyla. Anadolu'da Kaškalar. Ankara: Hel Yayıncılık, 2016.

Murat, Leyla. "Hitit Dünyasında Gaşgaların Yeri”, Sedat Alp, Algül Süel (haz.) III. Uluslararasl Hititoloji Kongresi Bildirileri (16-22 Eylül 1996), 1998: 435-443.

Murat, Leyla. "Hitit Coğrafyasında Yukarı Ülke ve Tarihi Önemi", Sekine Karakaş (haz.) Türkiye'de Sosyal Bilimlerin Gelişmesi ve Dil ve Tarih-Coğrafya Fakültesi Sempozyumu Bildirileri (24-26 Nisan 1996), 175-188. Ankara, 1998.

Müller-Karpe, Andreas. "Anatolische Bronzeschwerter und Südosteuropa", ed. C. Dobiat, Festschrift für Otto-Herman Freye zum 65. Geburtstag. 431-444. Hitzeroth, 1994.

Müller-Karpe, Andreas ve Müller-Karpe, Vuslat. "Kuşakl1-Šarišša” ed. M. DoğanAlpaslan, M. Alpaslan, Hititler, Bir Anadolu Imparatorluğu. 220-227. İstanbul, 2013.

Neve, Peter. "Die Grabungen aus Büyükkale" Mitteilungen der Deutschen Orientgesellschaft 95 (1965): 35-68.

Otten, Heinrich, Die Apologie Hattusilis III: das Bild der Überlieferung, (StBoT 24) (Wiesbaden: Otto Harrassowitz, 1981)

Özgüç, Tahsin. "Tokat Menşeili Bir Hitit Boğa Baş// Ein Hethitischer Stierkopf aus Tokat", Anadolu I (1956): 53-58. 
Özgüç, Tahsin. Maşathöyük II, Boğazköy'ün Kuzeydoğusunda Bir Hitit Merkezi. Ankara: Türk Tarih Kurumu Yayınları, 1982.

Özgüç, Tahsin. İnandıktepe, Eski Hitit Çağı'nda Önemli Bir Kült Merkezi. Ankara: Türk Tarih Kurumu Yayınları, 1988.

Özgüç, Tahsin. "Alaca Höyük, İmparatorluğun Çekirdek Bölgesinde Bir Kült Merkezi” ed. W. Jacob, Hititler ve Hitit Imparatorluğu, 1000 Tanrll Halk. 468-469. Bonn, 2002.

van den Hout, Theo. "Pala, Palaer, Palaisch", Reallexikon der Assyriologie 10 (20032005): 191-192.

van den Hout, Theo. "Hitit Krallı̆ğ ve İmparatorluğu'nun Kısa Tarihi”, ed. M. DoğanAlpaslan, M. Alpaslan, Hititler, Bir Anadolu İmparatorluğu. 22-47. İstanbul, 2013.

von der Osten, Hans Henning. The Alişar Höyük Seasons of 1930-1982 Part II. Chicago: The University of Chicago Press, 1937.

von Schuler, Einar. Die Kaskäer. Berlin: De Gruyter, 1965.

von Schuler, Einar. “Kaskäer”, Reallexikon der Assyriologie 5 (1976-80): 460-463.

Seeher, Jürgen. "Boğazköy-Hattuşa 1997 Yılı Çalışmaları", Koray Olşen, Fahriye Bayram, Adil Özme, Kemalettin Ataş, Haydar Dönmez, Ceyhan Süvari, haz. Kazı Sonuçları Toplantısı XX-I (1999): 181-192. Ankara, 2000.

Seçer, Sezer. Yazılı Belgeler Işığında Lukka, Pedašša ve Walma Ülkeleri'nin Tarihi ve Tarihi Coğrafyası. İstanbul Üniversitesi, Hititoloji Bilim Dalı, Yayınlanmamış Yüksek Lisans Tezi, İstanbul, 2012.

Schachner, Anreas. "Die Ausgrabungen in Boğazköy-Hattuscha 2006" Archäologische Anzeiger 2007/1: 67-93.

Schoop, Ulf Dietrich. "Çamlıbel Tarlası ve Kuzey-Orta Anadolu'da Geç Kalkolitik Dönem” İpek Önder haz. 1. Çorum Kazı ve Araştırmalar Sempozyumu, 137160. Çorum, 2011.

Singer, Itamar ve Hoffner, Harry. Hittite Prayers. Atlanta: Society of Biblical Literature, 2002.


Ülkesi’ Üzerine Yeni Bir Değerlendirme”, Belleten LXXX-288 (2016): 357-370.

Starke, Frank. "Hitit İmparatorluğu'nun Yapısı", ed. W. Jacob, Hititler, Bin Tanrıll Halk. 530-532. Bonn: Kunst-und Ausstellungshalle der Bundesrepublik Deutschland, 2002.

Strabon, Geograpika. (çev. A. Pekman), İstanbul: Arkeoloji ve Sanat Yayınları, 2015.

Strobel, Karl.“Altphrygische Religion und Königsideologie-Eine weitere Brücke zur hethitischen Großreichszeit?”, Colloquium Anatolicum IX (2010): 29-85.

Ünal, Ahmet. "Hethitische Hymnen und Gebete", Otto Kaiser ed. Orakel, Rituale Bau- und Votivinschriften Lieder und Gebete (TUAT II/6), 791- 817. Gütersloh, 1991. 
Ünal, Ahmet. "A Hittite Mycenaean Type B Sword from the Vicinity of Kastamonu, Northwest Turkey", Bulletin of the Middle Eastern Culture Center in Japan XI (1999): 207-226.

Ünal, Ahmet. Hititler Devrinde Anadolu II. İstanbul: Arkeoloji ve Sanat Yayınları, 2003.

Ünal, Ahmet. Hititler Devrinde Anadolu III. İstanbul: Arkeoloji ve Sanat Yayınları, 2005.

Ünal, Ahmet. Hititçe Çok Dilli El Sözlüğü II (N-Z). Hamburg: Verlag Dr. Kovac, 2007.

Ünal, Ahmet. Eski Anadolu Siyasi Tarihi. Ankara: Bilgin Kültür Sanat, 2018.

Philip, Graham. Metal Weapons of the Early Bronze Ages in Syria-Palestine Part III. Oxford: B.A.R., 1989.

Przeworski, Stefan. "Der Grottenfund von Ordu”, Archiv Orientalni 7 (1935): 390-414.

Roodenberg, Jacob. "Stratigraphy and Architecture", ed. J. Roodenberg, The Illpinar Excavations I. Five Sesons of Fieldwork in NW Anatolia 1987-91. 35-76, İstanbul, 1995.

Trémouille, Marie-Claude. ${ }^{d}$ Hebat, Une Divinité Syro-;Anatolienne, Eothen 7, Firenze: Logismo, 1997.

Tezcan, Burhan."Yeni Horoztepe Buluntuları" Anadolu V (1961): 13-46.

Tuna, Celal. Orta Karadeniz Bölgesi Sahil Kesiminde Geleneksel Mimari. İstanbul: Arkeoloji Sanat Yayınları, 2008.

Yalçın, Ünsal, Pulak Cemal, Slotta Rainer (ed.). Uluburun Gemisi 3000 Yll Önce Dünya Ticareti. Bochum: Deutsches Bergbau-Museum, 2006.

Yakar, Jak ve Dinçol, Ali. "Remarks on the Historical Geography of north-central Anatolia during the pre Hittite and Hittite periods", Tel Aviv 1 (1974): 85-99.

Yakar, Jak ve Dinçol, Ali. "The Archaeology of the Kaška", IV Congresso Internazionale di Hitologia, Roma, 5-9 Settembre 2005, Studi Micenei ed Egeo-Anatolici Vol. L-II (2008):817-827.

Yakubovich, Ilya. "Were Hittite Kings Divinely Anointed? A Palaic Invocation to The Sun-God and Its Significance for Hittite Religion", Journal of Ancient Near Eastern Religions 5 (2006): 107-137.

Yıldırım, Tayfun. "A Group of Hittite Bronze Objects from the Seben District of Bolu", Anatolica XXVII (2001): 127-144.

Yıldırım, Tayfun. "New Scenes on the Second Relief Vase from Hüseyindede and Their Interpretation in the Light of the Hittite Representative Art" Studi Micenei ed Egeo-Anatolici Vol. L (2008): 837-850. 




1 Kastamonu-Kınık

2 Bolu-Seben

3 Buz Mağaras

4 Okçular Kale Ini

5 Ören Höyük

6 Semercitepe

Asker Hoy

9 Salman Höyük

10 Cengelli

11 İmrentepe

12 Taşköprü Yolu Höyük

Figür 1: Batı Karadeniz Bölgesi'nde Geç Tunç Çăg'a ait buluntu elde edilen merkezler (Google Earth üzerinden geliştirilmiştir).

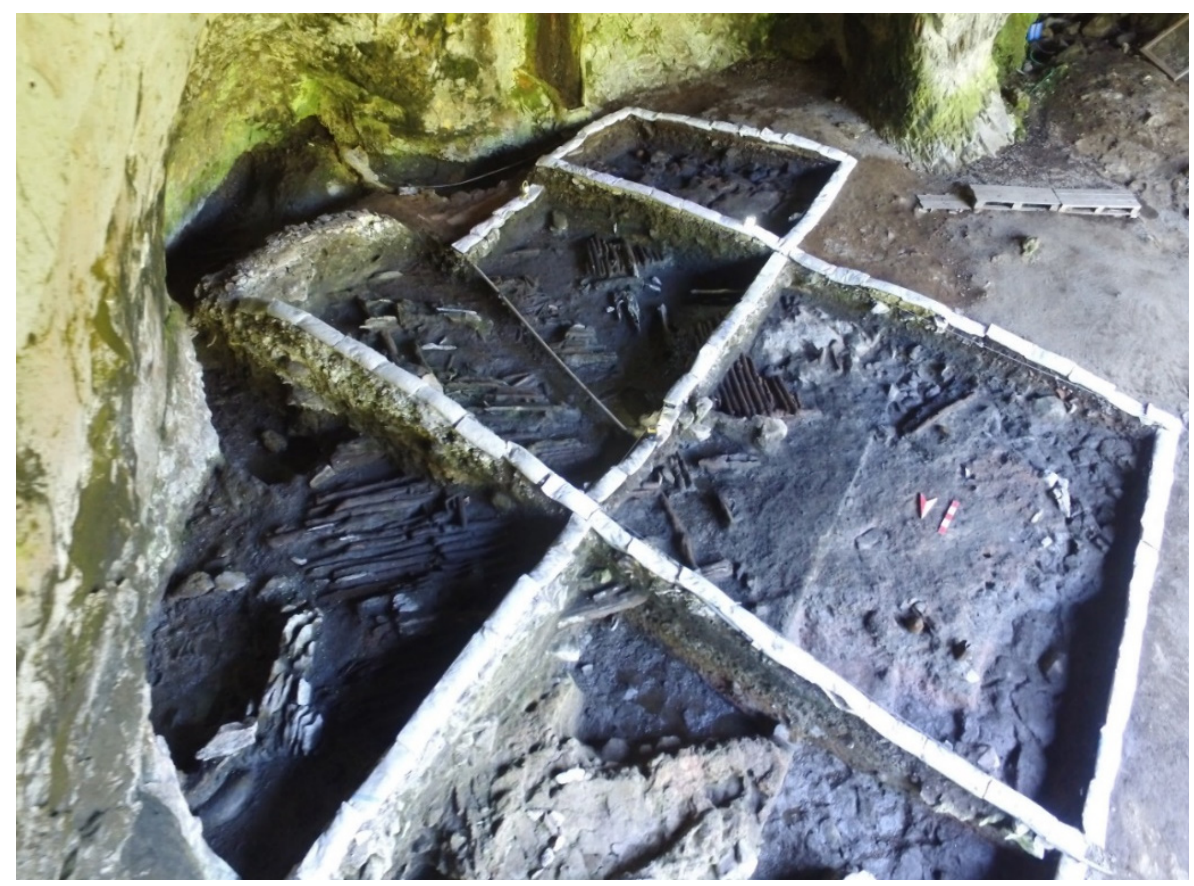

Figür 2: III. Tabakaya ait mimari bulgular (Kaynak: İnönü Mağarası Kazısı Arşivi) 


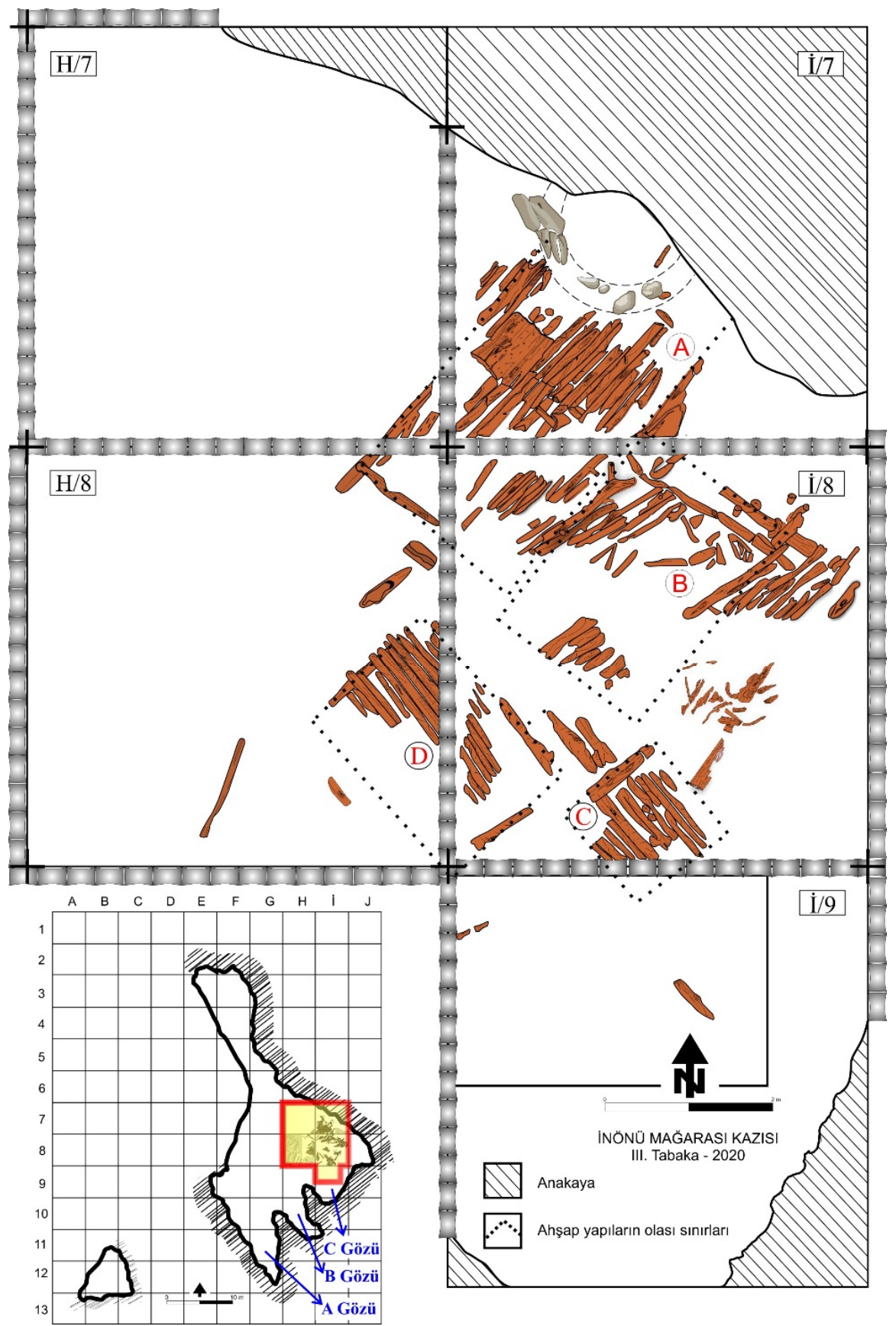

Figür 3 III. Tabakaya ait mimari bulguların çizimi ve mağara içindeki konumu (Çizim: Ümmügülsüm Uğurlu) 

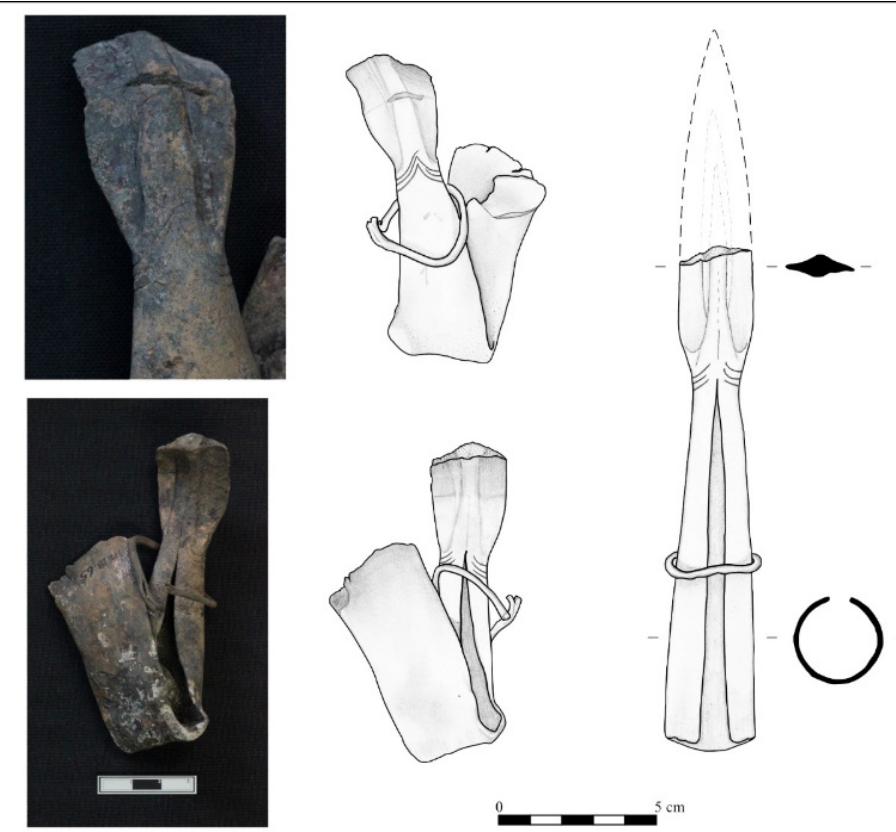

Figür 4 III. Tabakaya ait kovanlı mızrak ucu (Çizim: Burak Kader)



Figür 5 III. Tabakaya ait hançer (Çizim: Burak Kader) 


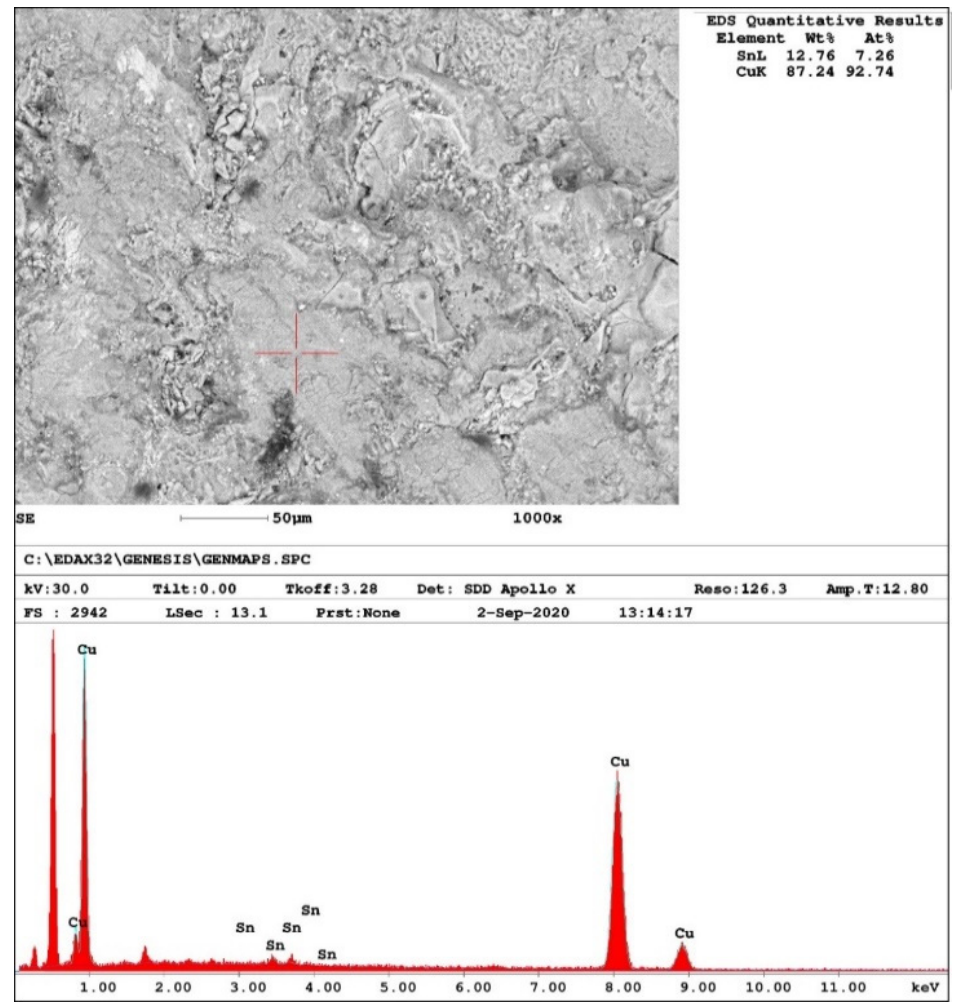

Figür 6 III. Tabakada bulunan boğa heykelciğinin SEM-EDS analizi sonucu (Kaynak: İnönü Mağarası Kazısı Arşivi)

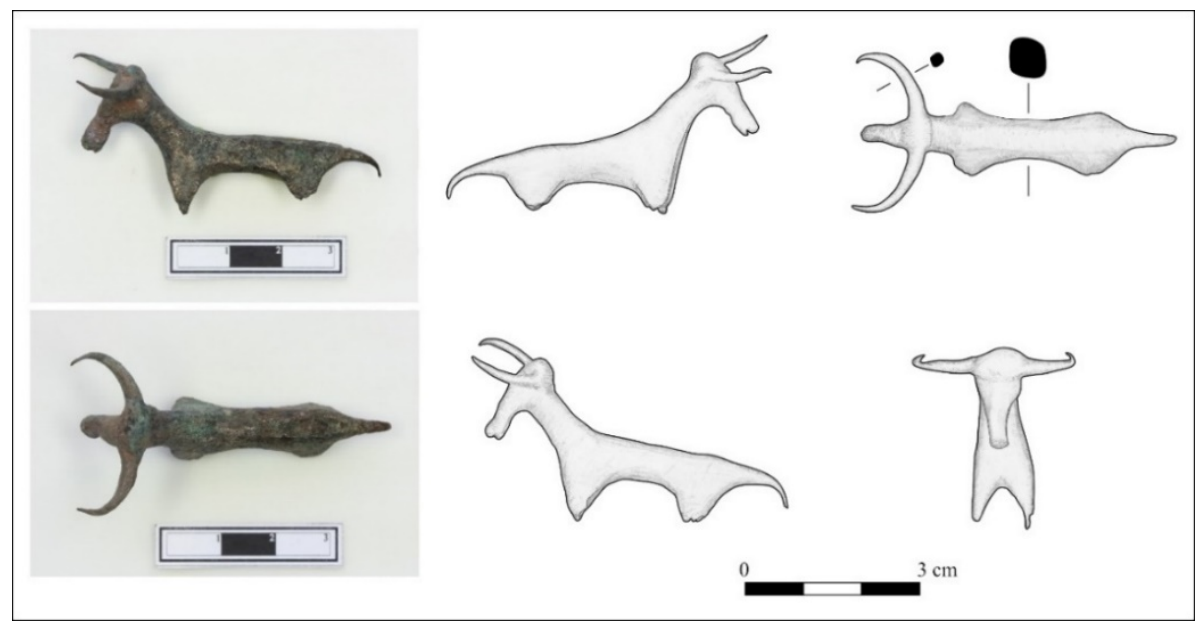

Figür 7 III. Tabakaya ait boğa heykelciği (Çizim: Burak Kader) 


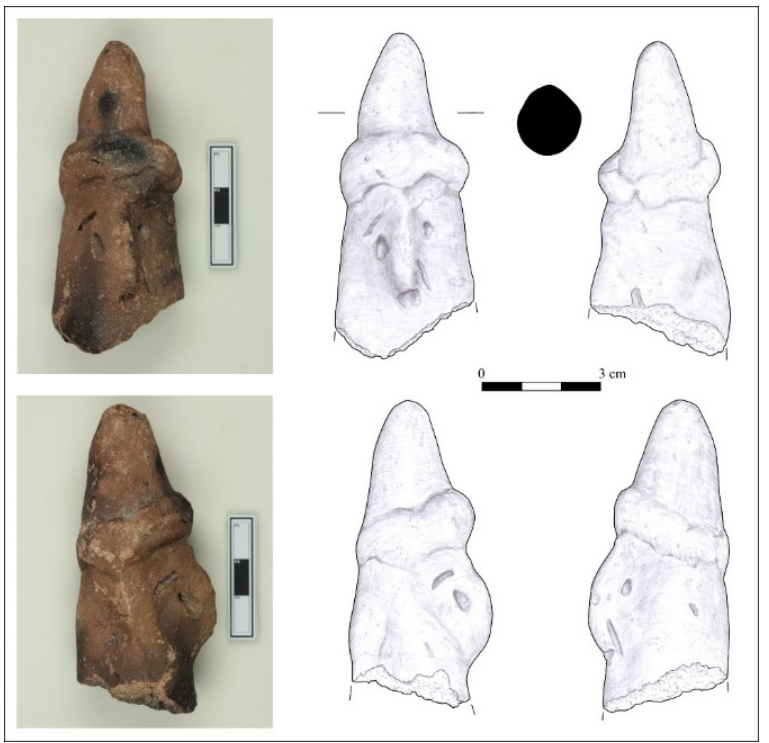

Figür 8 III. Tabakaya ait heykelcik başı (Çizim: Burak Kader)

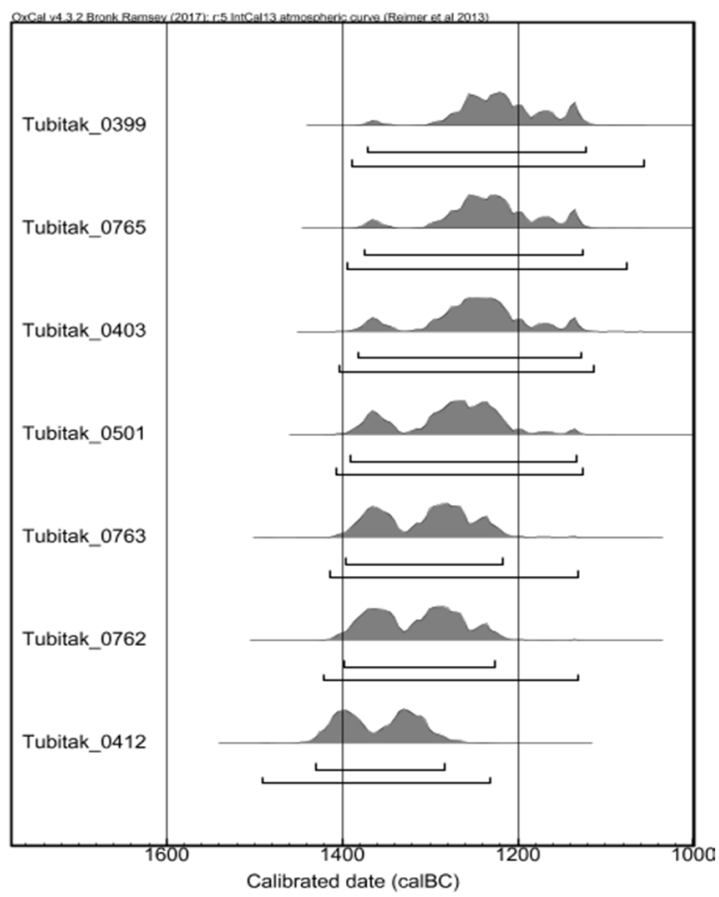

Figür 9 III. Tabakaya ait karbon örneklerinin analiz sonuçları (Kaynak: İnönü Mağarası Kazısı Arşivi) 